\title{
Investor Overconfidence and the Increase in Idiosyncratic Risk
}

\author{
Eric C. Chang*; Yan Luo \\ School of Business, Faculty of Business and Economics, University of Hong Kong, \\ Pokfulam Road, Hong Kong
}

\begin{abstract}
We adopt investor sentiment, stock turnover, and misvaluation as proxies for investor overconfidence, and document that idiosyncratic risk is positively correlated with investor overconfidence at both the individual stock level and the market level. And controlling for investor overconfidence reduces the positive time trend in idiosyncratic risk documented widely. The results are robust when firm size, age, stock price, profitability and growth options are controlled. We argue, therefore, that idiosyncratic risk is associated with investor overconfidence and that changes in overconfidence over time could help to explain the time pattern of idiosyncratic risk.
\end{abstract}

Key words: Overconfidence; Idiosyncratic Risk

JEL classification: D82, D83, G12, G14

*Corresponding author. Tel: (852) 2857-8347; fax: (852) 2858-5614; e-mail: ecchang@business.hku.hk. 


\title{
Investor Overconfidence and the Increase in
}

\author{
Idiosyncratic Risk
}

\begin{abstract}
We adopt investor sentiment, stock turnover, and misvaluation as proxies for investor overconfidence, and document that idiosyncratic risk is positively correlated with investor overconfidence at both the individual stock level and the market level. And controlling for investor overconfidence reduces the positive time trend in idiosyncratic risk documented widely. The results are robust when firm size, age, stock price, profitability and growth options are controlled. We argue, therefore, that idiosyncratic risk is associated with investor overconfidence and that changes in overconfidence over time could help to explain the time pattern of idiosyncratic risk.
\end{abstract}

Key words: Overconfidence; Idiosyncratic Risk

JEL classification: D82, D83, G12, G14 
The finding of Campbell et al. (2001) that idiosyncratic risk has increased noticeably over the past 30 years is followed by a surge of work trying to offer explanations for this phenomenon. The existing literature suggests that the increase in idiosyncratic risk may be related to institutional holdings (Xu and Malkiel, 2003), firm age (Pastor and Veronesi, 2003), deteriorating yet increasingly volatile earnings (Wei and Zhang, 2006), or changes in growth options (Cao et al., 2007).

Much of the previous research investigates the phenomenon of the increase in idiosyncratic risk within the efficient market framework, and attributes the positive trend in idiosyncratic risk to changes in fundamental values over time. However, existing studies of stock price movement also argue that the volatility of stock prices is too high to be attributed to changes in values (Shiller, 1981; Roll, 1988; Black, 1986). Evidence of excess stock price volatility over value variation suggests that examining the increase in idiosyncratic risk based only on the efficient market view may be insufficient, and that seeking complementary explanations based on a behavioral finance perspective may be fruitful.

The behavioral finance perspective maintains that people are affected by cognitive biases and considers the influence of these biases on the behavior of market participants. One psychological bias that is often related to market volatility in the behavioral finance literature is "overconfidence". This bias is first discussed in the psychological literature in the 1970s when psychologists find that people tend to overestimate their sophistication of skills. The term "overconfidence," is later on 
adopted in the finance field to describe the tendency of investors to overestimate the precision of their private information.

According to the efficient market hypothesis, overconfidence, as a nonfundamental factor carrying no information, should have no influence on financial markets. Anecdotal evidence and research in the behavioral finance literature, however, suggest that overconfidence does matter in a world in which heterogeneous beliefs and arbitrage constraints are present. Evidence has been found to support the relation between overconfidence and trading volume, price, profits, stock volatility, and market anomalies that lack justification from traditional finance theories (Benos, 1998; Barber and Odean, 2001; Daniel, Hirshleifer, and Subrahmanyam, 1998, 2001; Scheinkman and Xiong, 2003).

The link between overconfidence and excess stock volatility is well-established. Daniel et al. (1998) incorporate investor overconfidence into their model by assuming that overconfident investors use both public and private information, but overestimate the precision of the latter. They argue that overconfidence increases unconditional stock volatility, as overconfidence results in the initial overreaction of investors to private signals and hence greater need for price reversals when public signals are later revealed. The more overconfident investors are, the more the price swings away from its true value, leading to a more severe adjustment later on and higher stock price volatility. The relation between overconfidence and excess price volatility predicted by Daniel et al. is consistent with the findings of Odean (1998), 
Benos (1998), Gervais and Odean (2001), Scheinkman and Xiong (2003), and Caballe and Sakovics (2003).

Whereas previous studies usually address the relationship between overconfidence and total stock volatility, in this paper we argue that if the private information received by overconfident investors is largely firm specific, one could expect much of the high stock volatility resulting from overconfidence to be idiosyncratic. It is therefore reasonable to expect overconfidence to be positively related to idiosyncratic risk.

Furthermore, studies on the evolution of overconfidence argue that overconfident investors can better survive in the market, as they trade aggressively and intimidate rational or underconfident investors to trade less than optimal (Kyle and Wang (1997)), explore the environment more actively (Bernardo and Welch (2001)), undertake challenging tasks more often (Weinberg (2006)) and are willing to take on more risks (Hirshleifer and Luo (2001)). These studies conclude that overconfidence works to the advantage of investors. Therefore, overconfidence is pervasive and grows over time, before reaching some extreme value. If overconfidence is associated with high idiosyncratic risk and overconfidence increases as time passes by, an increase in idiosyncratic risk over time is not surprising.

We therefore propose three hypotheses: H1) idiosyncratic risk is cross-sectionally positively related with investor overconfidence at the individual stock level; H2) aggregated idiosyncratic risk is positively related with investor overconfidence at 
the market level; and H3) changes in overconfidence over time contribute to the positive time trend in aggregated idiosyncratic risk.

In our empirical work, we employ three proxies for investor overconfidence: investor sentiment, stock turnover, and stock misvaluation.

Investor sentiment reflects changes in trading strategies that are not fully driven by solid information about changes in fundamentals, and therefore could largely result from investor overconfidence (Caballe and Sakovics, 2003). We adopt the sentiment index developed by Baker and Wurgler (2006), which is based on the common variation in six underlying proxies for sentiment: the closed-end fund discount, NYSE share turnover, the number of IPOs, the average first-day returns on IPOs, the share of equity issues in total equity and debt issues, and the dividend premium. $^{1}$

Trading volume is perhaps the most widely accepted measure of overconfidence. Overconfidence in one's own private information and valuation of stocks promotes heterogeneous beliefs among market participants, and increases trading. Shiller (2000) states that overconfidence, however generated, appears to be a fundamental factor promoting the high volume of trade. Empirical evidence has been found to support this argument (Barber and Odean, 2001; Meir et al., 2006).

\footnotetext{
${ }^{1}$ This sentiment index is somewhat related to market conditions, which enhances our justification for using it as an overconfidence proxy. Several studies (see, for example, Daniel et al. (1998), Gervais and Odean (2001), and Odean (1998)) suggest that overconfidence is greater following market gains. This intuition is based on biased self-attribution, which describes people's tendency to give themselves credit for their successes and to blame external factors for their failures. As investors in equity markets generally hold long potions, bullish market conditions will add to their overconfidence as they attribute profits to their ability to correctly choose stocks.
} 
We identify stock misvaluation as the third proxy for overconfidence. According to Daniel et al.(1998), overconfident investors overreact to private information the precision of which is overestimated, and the stock price deviates from its true value as a result. Positive signals cause stocks to be overvalued, while negative signals drive stock prices to be undervalued. Hence, misvaluation can capture investor overconfidence by measuring the degree to which investors overshoot. The relation between overconfidence and misvaluation is supported by Scheinkman and Xiong (2003), who argue that investor overconfidence contributes to a significant bubble component in asset prices. We follow the method of Rhodes-Kropf et al. (2005) to measure misvaluation. The methodology is described in detail in section I.A.

Turnover and misvaluation measures have data at the individual stock level, and can be aggregated to get measures at the market level. The investor sentiment measure, however, applies to overconfidence only at the market level. Therefore, we use turnover and misvaluation in cross-sectional regressions at the individual stock level, and all three measures in time-series regressions at the market level.

Our empirical results support our hypotheses. We find that our overconfidence measures are positively correlated with idiosyncratic risk, both in cross-sectional regressions at the individual stock level, and in time-series regressions at the market level. And after adding the three overconfidence measures, the positive time trend in idiosyncratic risk is reduced in time-series regressions.

To examine the robustness of the relationship between overconfidence measures 
and idiosyncratic risk, we perform tests in which we control several variables suggested in the literature that are related to the observed idiosyncratic risk time pattern, including firm size, age, profitability and growth option. We find that our overconfidence measures are robust in the presence of these variables. These results imply that in addition to variations in fundamental values, changes in investor behavior are also a determinants of idiosyncratic risk.

We also examine the time trend of overconfidence over time. All the overconfidence measures we employ manifest, as does idiosyncratic risk, a significant positive trend over the whole sample period from January 1971 to December 2005. However, there is a significant decrease in overconfidence after 2000. Interestingly, we find that idiosyncratic risk drops over the same period as well, a phenomenon that is also mentioned in Brandt et al.'s (2005) study. We argue that the overlapping of the time patterns of overconfidence and idiosyncratic risk is not coincidence. Instead, changes in investor overconfidence over time could be one determinant of the time pattern of idiosyncratic risk.

The rest of this paper is organized as follows. Section I introduces the data and methodology. Sections II and III present the results of cross-sectional and timeseries tests, respectively. Section IV discusses the evolution of overconfidence and idiosyncratic risk over time, and section VI concludes the paper. 


\section{Data and Methodology}

\section{A. Data and Methodology}

The stock return data are from the Center for Research in Security Prices (CRSP), and the accounting data are from COMPUSTAT. Our sample includes stocks listed on the AMEX, NYSE, and NASDAQ. Due to data limitations, measures that are based on COMPUSTAT data are calculated from January 1976 to December 2005. All other measures cover the period from January 1971 to December 2005. Only stocks with available daily returns of current month and market capitalization data at the end of the previous month are kept in the sample. All accounting data in this paper are winsorized at both the upper and lower $2.5 \%$ levels. $^{2}$

Idiosyncratic risk is calculated in two ways. In cross-sectional regressions, the idiosyncratic risk of an individual stock is the variance of residuals from regressing that stock's daily returns on the Fama-French four factors within each month. ${ }^{3}$ For time-series regressions, we adopt the beta free method to calculate market-level idiosyncratic risk, following Campbell et al. (2001), Wei and Zhang (2006), and Cao et al. (2007). ${ }^{4}$ The daily return of an individual stock over the daily CRSP value weighted market return is calculated, and the variance of this excess return is calculated monthly. In month $t$, the variances of excess returns on available stocks

${ }^{2}$ We follow Tim et al. (2007) in choosing the $5 \%$ winsorizing level.

${ }^{3}$ The Fama-French four factors used are the market excess return factor, small-minus-big factor, high-minus-low factor, and momentum factor.

${ }^{4}$ We have also tried to measure market-level idiosyncratic risk by value weighting the idiosyncratic risks of individual stocks calculated under the first method. The results are qualitatively the same. 
are value weighted and multiplied by the number of trading days in the month to get the aggregate idiosyncratic risk, $V_{t}$.

$S E N T_{t}^{\perp}$ denotes investor sentiment at month $t$. For our empirical work, we employ the sentiment index developed by Baker and Wurgler (2006) in which the influence of business cycles has been removed.

$T O_{i, t}$ is the turnover of firm $i$ 's stock at time $t$. It is calculated by scaling the trading volume of firm $i$ 's stock in month $t$ by its total number of shares outstanding. $T O_{i, t}$ of each firm are value weighted by the market capitalization of firms at the end of the previous month to get the aggregated measure $T O_{t}$.

Return on equity, $R O E_{i, t}$, is firm $i$ 's income before extraordinary items over its book value of equity in quarter $t$. Stocks with a negative book value of equity are deleted. Earnings reporting date for individual firms are obtained from CRSP database. ${ }^{5}$ Following Wei and Zhang (2006) and Cao et al. (2007), we match the quarterly accounting data with monthly stock return data through earnings reporting date. The quarterly $R O E_{i, t}$ data are then transformed into monthly data. If one firm has missing monthly $R O E_{i, t}$ data at time $t$, its most recently released return-on-equity data will be used instead. ${ }^{6} V R O E_{i, t}$ is the variance of monthly $R O E_{i, t}$ over the previous 3 years. Firm months with fewer than nine observations in

\footnotetext{
${ }^{5}$ For stocks with $R O E_{i, t}$ data but missing earnings reporting date, we set the reporting month to be the third month after the fiscal quarter, following Tim et al. (2007).

${ }^{6}$ We delete observations for which the most recently released accounting information dates back to more than six months previously, as such remote information may not accurately depict a firm's profitability at the current stage. Extending the period from six months to twelve months does not qualitatively change our results.
} 
that period are deleted. Monthly $R O E_{i, t}$ and $V R O E_{i, t}$ are then value weighted to get $R O E_{t}$ and $V R O E_{t}$, respectively.

In their paper, Cao et al. (2007) employ five proxies to measure growth options and use these proxies to explain the positive trend in idiosyncratic risk. Among these proxies, the ratio of market value to book value has the strongest explanatory power for the trend in idiosyncratic risk and is one of the most robust proxies throughout the tests. However, when one allows for the possibility of asset misvaluation, this ratio arguably contains two components. That is, letting $V$ denote the true value of the firm, one can write

$$
(M / B)_{i, t}=(M / V)_{i, t} \times(V / B)_{i, t}
$$

where $M$ and $B$ stand for the observed market value and book value, respectively. In equation (1), with $(M / V)_{i, t}$ capturing misvaluation, we argue that $(V / B)_{i, t}$ is the bona fide measure of firm $i$ 's growth option at time $t$. Whether it is the growth option component, the misvaluation component, or the combination of the two that drives the results in the study of Cao et al. is an empirical issue. The misvaluation component indeed can be greatly affected by investor overconfidence, as discussed. For our empirical work, we follow the method of Rhodes-Kropf et al. (2005) to separate the $M / B$ ratio into a misvaluation component and long-term growth component.

The decomposition methodology is as follows. First we group firms into 12 
industries based on Fama and French's industry classification system. Then we perform the following cross-sectional regression within each industry quarterly:

$$
M_{i, t}=\beta_{0 j t}+\beta_{1 j t} B_{i, t}+\beta_{2 j t} N I_{i, t}^{+}+\beta_{3 j t} I_{(<0)} N I_{i, t}^{+}+\beta_{4 j t} L E V_{i, t}+\epsilon_{i, t},
$$

where $i$ stands for an individual stock and $j$ stands for the industry to which the stock belongs, $M_{i, t}$ is the market value per share of firm $i$ at quarter t, $B_{i, t}$ is the corresponding book value of common equity per share, $N I_{i, t}^{+}$is the absolute value of net income per share, $I_{(<0)} N I_{i, t}^{+}$is an indicator function for negative net income observations, and $L E V_{i, t}$ is a measure of the degree of leverage defined as the total liabilities scaled by total assets. ${ }^{7}$ Observations with $L E V_{i, t}$ less than 0 or greater than 1 are deleted.

For each industry $j$, the quarterly industry coefficients are averaged over the whole sample period (denoted as $\overline{\beta_{0 j}}, \overline{\beta_{1 j}}, \overline{\beta_{2 j}}, \overline{\beta_{3 j}}$, and $\overline{\beta_{4 j}}$, respectively) and then applied to firms within the industry to get the estimated true value per share, $V_{i, t}$, for each firm at each quarter:

$$
V_{i, t}=\overline{\beta_{0 j}}+\overline{\beta_{1 j}} B_{i, t}+\overline{\beta_{2 j}} N I_{i, t}^{+}+\overline{\beta_{3 j}} I_{(<0)} N I_{i, t}^{+}+\overline{\beta_{4 j}} L E V_{i, t}
$$

Because over- and undervaluation tend to cancel each other out within each

${ }^{7}$ We follow Tim et al. (2007) in defining market value and book value based on COMPUSTAT data. $M_{i, t}$ and $B_{i, t}$ are calculated accordingly:

$M_{i, t}=[$ Total Assets (data44)-Total Common Equity (data59) + Price (data14) * Common Shares Outstanding (data61)]/Common Shares Outstanding (data61);

$B_{i, t}=$ Total Assets (data44)/ Common Shares Outstanding (data61). 
industry over a long time, Rhodes-Kropf et al. (2005) argue that $V_{i, t}$ is a close measure of firm $i$ 's true value. Likewise, using $V_{i, t}$ as a proxy for $V$, we argue that $(V / B)_{i, t}$ is a cleaner measure of the growth option and is less influenced by misvaluation. We thus use $G O_{i, t}$ to denote firm $i$ 's growth option at time $t$ :

$$
G O_{i, t}=(V / B)_{i, t} .
$$

Accordingly, $(M / V)_{i, t}$ can be viewed as a measure of misvaluation of firm $i$ at time $t .(M / V)_{i, t}$ is greater than 1 when stock is overvalued and less than 1 when undervalued. To account for both the under-and overvaluation component in the subsequent analysis, we take the absolute value of the difference between $(M / V)_{i, t}$ and 1 for each firm at time $t$ as a measure of the degree of misvaluation:

$$
M I S V_{i, t}=\left|(M / V)_{i, t}-1\right| .
$$

We then match the quarterly accounting data with monthly stock return data and transform the quarterly data into monthly ones following the same methodology we applied in handling the $R O E$ data. The monthly $(M / B)_{i, t},(V / B)_{i, t},(M / V)_{i, t}$, $M I S V_{i, t}$ and $G O_{i, t}$ measures are value weighted to get $(M / B)_{t},(V / B)_{t},(M / V)_{t}$, $M I S V_{t}$ and $G O_{t}$. The time-series variances of the monthly measures over the previous 36 months are aggregated to get $(V M / B)_{t},(V V / B)_{t},(V M / V)_{t}$, and $V G O_{t}$. 


\section{B. Summary Statistics and Time Trends}

Column (2) of Table I(a) shows that aggregate idiosyncratic risk, on a whole, increases over the period from January 1971 to December 2005, as documented in previous work (see, for example, Campbell et al. (2001), Wei and Zhang (2006), and Cao et al. (2007)). And we could see that there is a sharp decrease in idiosyncratic risk in the period from year 2001 to 2005 . The mean and median of idiosyncratic risk are almost halved. This piece of evidence is consistent with Brandt et al.'s (2005) finding. They argue that in the three years ending in 2004, idiosyncratic risk falls to pre-1990s levels.

Panel A of Table I(b) reveals that each of the three overconfidence measures increases over time. Panel $\mathrm{B}$ shows that both $R O E_{t}$ and $V R O E_{t}$ generally increase as well.

Panel $\mathrm{C}$ of Table $\mathrm{I}(\mathrm{b})$ shows that $(M / B)_{t}$ and $(V M / B)_{t}$ do, on a whole, grow, which is consistent with the findings of Cao et al. (2007). The $(V / B)_{t}$ ratio, which we argue is a purer measure of the growth option, and the $(M / V)_{t}$ ratio manifest time trends similar to that of the $(M / B)_{t}$ ratio.

\section{[Insert Table I here]}

The time trends of idiosyncratic risk and the overconfidence measures are plotted in Figures 1 and 2, respectively. Figure 1 shows that idiosyncratic risk fluctuates from time to time, but generally increases before 2000. It jumps sharply in October 1987, which may be a result of the stock market crash in that period, 
and decreases after 2000. Figure 2 reveals that the three overconfidence measures manifest similar time trend, and that the time pattern of overconfidence measures is somewhat similar to that of the idiosyncratic risk.

[Insert Figure 1 and Figure 2 here]

We conduct preliminary tests (not reported for brevity) by regressing idiosyncratic risk and the three overconfidence measures on a time trend measure $t$, respectively. The results show that idiosyncratic risk increases significantly over time, but decreases after year 2000. Meanwhile, all three overconfidence measures have significantly positive time trend coefficients over the whole sample period, and negative ones in the last five years.

C. Idiosyncratic Risk, $M / B$ Ratio, and $M / B$ Components

Cao et al. (2007) find that idiosyncratic risk is positively correlated with both the level and variance of the $M / B$ ratio. In this sub-section, we examine the relationship of idiosyncratic risk with the $M / B$ ratio and with its two components. This can be viewed as a re-examination of the findings of Cao et al. (2007). We regress $V_{t}$ on $(M / B)_{t-1},(V / B)_{t-1}$, and $(M / V)_{t-1}$, respectively. In each regression, we also include their variances.

[Insert Table II here]

The results in Table II indicate that the coefficients on $(M / B)_{t-1}$ and its variance, $(V M / B)_{t-1}$, are significantly positive, consistent with the findings of Cao 
et al. (2007). The regression results in rows (3) and (4) show that the explanatory power of $(M / B)_{t-1}$ is actually shared by each of its two components: the coefficients on $(V / B)_{t-1}$ and $(M / V)_{t-1}$ are both significantly positive at the $1 \%$ level. However, for the variances, whereas the coefficient on $(V V / B)_{t-1}$ is significantly positive at the $1 \%$ level, the coefficient on $(V M / V)_{t-1}$ is insignificant.

The results in row (3) of Table II show that although the $M / B$ ratio could be contaminated by misvaluation, its $V / B$ component, which is arguably a better measure of the long-term growth option, is not only significant with the predicted sign but also able to eliminate the trend in idiosyncratic risk. Moreover, we find that the positive relation between $(V M / B)_{t-1}$ and $V_{t}$ is largely contributed by the variance of the $V / B$ ratio. In the subsequent tests, we separate the $M / B$ ratio, and measure growth option and misvaluation based on its two components.

\section{Cross-Sectional Tests}

\section{A. Idiosyncratic Risk and Overconfidence: Cross-Sectional Tests}

H1 predicts that stocks that are more subject to investor overconfidence influence will have higher idiosyncratic risk. In this section, we perform crosssectional regressions to test this prediction. We add several control variables in the regressions, including stock return, size, leverage ratio, age, stock price, $R O E$, and growth options. The cross-sectional regressions are performed monthly. The mean and standard errors of the slope coefficients are estimated across the whole sample 
period. The results are shown in Table III. ${ }^{8}$

[Insert Table III here]

The coefficient on $R E T_{i, t-1}$ is significantly negative. Firm size is negatively correlated with idiosyncratic risk; that is, smaller firms tend to have higher idiosyncratic risk. The relation between leverage and idiosyncratic risk is ambiguous, as suggested by previous research (Campbell et al., 2001; Wei and Zhang, 2006). The coefficient on $A G E_{i, t}$ is negative in column (1), consistent with Pastor and Veronesi's (2003) argument that younger firms with a shorter history are more likely to have higher idiosyncratic risk. However, when more variables are controlled in subsequent columns, the coefficient on $A G E_{i, t}$ sometimes turns insignificant or positive.

The coefficient on stock price, $P R C_{i, t-1}$, is significantly negative, consistent with Brandt et al.'s (2005) finding that low-priced stocks have high idiosyncratic risk. The relation between stock price and idiosyncratic risk is robust across columns. The coefficients on $R O E_{i, t-1}$ and $V R O E_{i, t-1}$ are significantly negative and positive, respectively.

To examine the relation between idiosyncratic risk and growth option, we start by measuring growth option using the market value to book value ratio, $(M / B)_{i, t}$, following Cao et al. (2007). In column (3), we see that the coefficients $(M / B)_{i, t-1}$ and $(V M / B)_{i, t-1}$ are both significantly positive. We then replace the $M / B$ ratio with

\footnotetext{
${ }^{8}$ In cross-sectional regressions, we only stock turnover and stock misvaluation as proxies for investor overconfidence. The sentiment index is not examined here as it has data only at the market level.
} 
the $G O$ measure in column (4), which we argue is a purer measure of growth option. Again, the coefficients on $G O_{i, t-1}$ and $V G O_{i, t-1}$ are both significantly positive.

Next, we examine the performance of the overconfidence measures. Stock turnover, $T O_{i, t-1}$, and misvaluation, $M I S V_{i, t-1}$, are used as overconfidence proxies in columns (5) and (6). The coefficients on both measures are significantly positive, as predicted.

In the last four columns, all variables are pooled together. The coefficients on $S I Z E_{i, t-1}, P R C_{i, t-1}, R O E_{i, t-1}$, and $V R O E_{i, t-1}$ remain significant with predicted signs. The coefficient on $(M / B)_{i, t-1}$ becomes negative in columns (7) and (8). The coefficient on $G O_{i, t-1}$, however, remains significantly positive in columns (9) and (10). And the coefficients on both overconfidence measures, $T O_{i, t-1}$ and $M I S V_{i, t-1}$, are consistently significantly positive.

\section{B. Cross-Sectional Tests in Subsamples}

Results in Table III suggest that idiosyncratic risk is higher for smaller stocks, for younger stocks, and for lower-priced stocks. To examine the robustness of the results, we conduct cross-sectional tests in subsamples in this section. Stocks are divided into subgroups based size, age, or price. Results of subsample tests are presented in Table IV.

\section{[Insert Table IV here]}

In panels $\mathrm{A}$ and $\mathrm{B}$, stocks are partitioned based on size. Panel A uses stock turnover, $T O_{i, t-1}$, as the overconfidence proxy, while panel $\mathrm{B}$ uses misvaluation, 
$M I S V_{i, t-1}$. The coefficient on $T O_{i, t-1}$ is significantly positive in all size groups. The coefficient on $M I S V_{i, t-1}$ is significantly positive in the medium and large size stock groups, but turns negative in the small stock group. The coefficients on $S I Z E_{i, t-1}$, $P R C_{i, t-1}, R O E_{i, t-1}$ and $V R O E_{i, t-1}$ are significant with predicted signs across rows. The coefficient on $A G E_{i, t}$ is either insignificant or positive in small stocks. $G O_{i, t-1}$ is positively correlated with idiosyncratic risk, but the relation between $V G O_{i, t-1}$ and idiosyncratic risk is negative.

Stocks are grouped based on age in panels $\mathrm{C}$ and D. Both $T O_{i, t-1}$ and $M I S V_{i, t-1}$ are significantly positively correlated with idiosyncratic risk in all age subgroups. The relation between idiosyncratic risk and $P R C_{i, t-1}$ is vague here. The explanatory powers of $R O E_{t-1}$ and $V R O E_{i, t-1}$ are strong in all subgroups. The coefficient on $G O_{i, t-1}$ is significantly positive in most age subgroups, but the coefficient on $V G O_{i, t-1}$ is often insignificant or of opposite sign.

Panels E and F present results of subsample tests based stock price. The relation between idiosyncratic risk and $T O_{i, t-1}$ is robust across rows. The coefficient on $M I S V_{i, t-1}$ is significantly positive at $1 \%$ level in the medium-priced and highpriced stocks, but is negative in low-priced stocks. The coefficient on $S I Z E_{i, t-1}$ is significantly negative in three out of six rows. The relation between idiosyncratic risk and age is inconclusive. The coefficients on $P R C_{i, t-1}, R O E_{i, t-1}, V R O E_{i, t-1}$ and $G O_{i, t-1}$ are significant with predicted signs, while the coefficient on $V G O_{i, t-1}$ is either insignificant or with erroneous sign. 


\section{Cross-Sectional Tests in Subperiods}

We also perform the cross-sectional regressions in each five-year-subperiod. The results are reported in Table V. Panel A uses stock turnover as overconfidence measure, while Panel B uses misvaluation.

\section{[Insert Table V here]}

In panel $\mathrm{A}$, the coefficient on $T O_{i, t-1}$ is significantly positive in five out of six subperiods. The coefficient is insignificant in the 1991-1995 subperiod. And in panel B, the coefficients on $M I S V_{i, t}$ are significantly positive in all six subperiods. The relation between idiosyncratic risk and overconfidence measures are generally robust in subperiod tests.

For other variables, $S I Z E_{i, t-1}$ is consistently negatively correlated with idiosyncratic risk in all subperiods; the relation between idiosyncratic risk and $A G E_{i, t-1}$ and $P R C_{i, t-1}$ are not quite robust; the coefficients on $R O E_{i, t-1}$ and $V R O E_{i, t-1}$ are significantly negative and positive, respectively, in all subperiods; the coefficient on $G O_{i, t-1}$ is significantly positive in most subperiods, while the coefficient on $V G O_{i, t-1}$ is either insignificant or negative.

The results in Tables III, IV and V suggest that overconfidence is crosssectionally positively correlated with idiosyncratic risk. And the relation between idiosyncratic risk and overconfidence measures is robust when size, age, stock price, profitability and growth options are all controlled. 


\section{Time-Series Tests}

In this section, we examine the relation between overconfidence and idiosyncratic risk in time-series regressions.

\section{A. Idiosyncratic Risk and Overconfidence: Time-Series Tests}

To examine the relation between idiosyncratic risk and overconfidence predicted in $\mathrm{H} 2$ and $\mathrm{H} 3$, we first estimate the following time-series regression for each of the three overconfidence measures:

$$
V_{t}=\beta_{0}+\beta_{1} t+\beta_{2} O C_{t-1}+\epsilon_{t}
$$

where $O C_{t-1}$ represents the level of the overconfidence measures at time $t-1$.

$$
\text { [Insert Table VI here] }
$$

The regression results in Table VI show that before adding the overconfidence measures, the time trend coefficient is significantly positive. After they are added to regression, each of the three measures for overconfidence reduces the positive time trend in $V_{t}$. The coefficient on $t$ is reduced by around $40 \%$ in magnitude after controlling for $S E N T_{t-1}^{\perp}$. The coefficient on $S E N T_{t-1}^{\perp}$ is significantly positive with a $t$-value of 2.09. $T O_{t-1}$ has stronger power to reduce the positive time trend in idiosyncratic risk than $S E N T_{t-1}^{\perp}$. The coefficient on $t$ turns from significantly positive to negative. Meanwhile, the coefficient on $T O_{t-1}$ is significant at $5 \%$ level, and the adjusted $R$-square more than doubles. When $M I S V_{t-1}$ is added, the 
coefficient on $t$ again turns from positive to negative, and the coefficient on $M I S V_{t-1}$ is significant at $1 \%$ level.

In Table VI, the coefficients on $S E N T_{t-1}^{\perp}, T O_{t-1}$ and $M I S V_{t-1}$ are all significantly positive, as predicted, suggesting that idiosyncratic risk is high when investor sentiment is high, stock turnover is large, or misvaluation of stocks is severe. All these situations correspond to a market with high level of investor overconfidence.

\section{B. Idiosyncratic Risk, Profitability, Growth Option, and Overconfidence}

Wei and Zhang (2006) and Cao et al. (2007) find that profitability and growth options are correlated with idiosyncratic risk in time-series regressions and contribute to its time trend. In this section, we add both profitability and growth options in time-series tests, in addition to the overconfidence measures. The results are shown in Table VII.

\section{[Insert Table VII here]}

Column (1) shows the result of regressing idiosyncratic risk on the time trend measure $t$ only: the time trend coefficient is significantly positive with a $t$ value of 2.14. Columns (2), (3) and (4) add sentiment index, stock turnover, and misvaluation, respectively. The coefficient on $S E N T_{t-1}^{\perp}$ is significantly positive at $5 \%$ level, while the coefficients on $T O_{t-1}$ and $M I S V_{t-1}$ are significant at $1 \%$ level.

The level and variance of $R O E$ and $G O$ are included in the last three columns. The coefficients on $R O E_{t-1}$ and $V R O E_{t-1}$ lose their significance. The coefficient on 
$G O_{t-1}$ is significant when $S E N T_{t-1}^{\perp}$ or $T O_{t-1}$ are controlled, but turns insignificant when $M I S V_{t-1}$ is controlled. The coefficient on $V G O_{t-1}$ is significant only in column (7). After controlling changes in profitability and growth options, the coefficients on the three overconfidence measures remain significant.

Results in Table VII suggest that in explaining changes in idiosyncratic risk over time, the explanatory power of profitability is weak while that of growth option is relatively strong. And the control of both profitability and growth option does not diminish the explanatory powers of the overconfidence measures.

\section{Time-Series Tests in Subsamples}

In Wei and Zhang's (2006) study, $R O E_{t-1}$ and $V R O E_{t-1}$ performs well in explaining the time trend of idiosyncratic risk in full sample. However, when examine the time-series relation between idiosyncratic risk and $R O E$ in old firms, the profitability variables lose their explanatory powers. Cao et al. (2007) find that their growth option variables do not perform equally well in explaining the time trend of idiosyncratic risk in NYSE/AMEX stocks and in NASDAQ stocks. Therefore, we conduct time-series tests based on subsamples in this section. Subsamples are formed based on age and exchange market, respectively.

\section{C..1 Age}

We partition our sample into two sub-samples based on firm age, which is counted from one firm's first appearance in the CRSP to the end of the last year. Stocks are sorted based on age, and those that fall into the lowest and highest 
thirtieth percentiles are classified as young and old, respectively. Figure 3 plots the idiosyncratic risk of young and old stocks, and confirms Pastor and Veronesi's (2003) observation that the idiosyncratic risk of younger stocks is higher than that of older ones.

\section{[Insert Figure 3 here]}

The levels of turnover and misvaluation for these sub-samples are plotted in Figure 4. The sentiment proxy is dropped as it has data only for the market as a whole. Both turnover and misvaluation increase overall in each of the sub-samples, which suggests that the increasing trend in overconfidence is not simply capturing the effect of age.

\section{[Insert Figure 4 here]}

Interestingly, Figure 4 shows that the stock turnover and misvaluation of young firms are higher than those of old firms. This may have some implications for how overconfidence affects stocks with different characteristics. Baker and Wurgler (2006) find that sentiment does not affect different stocks equally. Their results show that returns of young stocks are more sensitive to investor sentiment than are old stocks. Similarly, it is possible that overconfidence affects different stocks differently: young stocks may be more subject to investor overconfidence influence than are old ones. The unequal impact that overconfidence has on different stocks is an interesting topic to explore in the future. 
We regress idiosyncratic risk on the overconfidence measures within each subsample, controlling for profitability and the growth option. The results are shown in Table VIII. Row (1) in each panel shows the result of regressing idiosyncratic risk on profitability and growth option measures simultaneously. Sentiment, turnover, and misvaluation are added in rows (2) to (4).

[Insert Table VIII here]

In panel $\mathrm{A}$ with younger stocks, the coefficients on $R O E_{t-1}$ and $V R O E_{t-1}$ are both significant across the rows, and are consistently negative and positive, respectively. However, they both turn out to be insignificant for the older stocks sample in panel B. The finding of the better performance of $R O E_{t-1}$ and $V R O E_{t-1}$ in younger stocks is consistent with Wei and Zhang's (2006) findings.

Unlike $R O E_{t-1}$ and $V R O E_{t-1}, G O_{t-1}$ is more powerful in panel B with older stock. The coefficient on $G O_{t-1}$ is only significant in row (3) in panel A, and the coefficient on $V G O_{t-1}$ is either insignificant or of opposite sign in both panels.

The overconfidence measures are included in rows (2), (3), and (4) in panels A and B. The coefficients on all three overconfidence measures are significantly positive at $1 \%$ level, in both the younger and older stock groups. These results suggest that the explanatory power of overconfidence is not constrained when profitability and the growth option are controlled, and that it is not driven simply by age effects. 


\section{C..2 Exchange Markets}

We next split stocks into NYSE/AMEX and NASDAQ stocks, based on where they are listed. This division helps to roughly control firm size, as larger firms are more likely to be listed in the NYSE/AMEX, whereas smaller firms are more likely to appear in the NASDAQ. Cao et al. (2007) find that their $G O_{t-1}$ and $V G O_{t-1}$ measures do not perform equally well in different markets: $G O_{t-1}$ is significant in both markets, whereas $V G O_{t-1}$ is significant only in the NYSE/AMEX market. They interpret this as the result of larger firms having more free cash flow and more flexibility in choosing and timing investments. The results of the sub-sample tests are presented in Table IX.

\section{[Insert Table IX here]}

Idiosyncratic risk is regressed on profitability and growth option measures in row (1) of panels $\mathrm{A}$ and $\mathrm{B}$. The coefficient on $R O E_{t-1}$ is insignificant in both panels. The coefficient on $V R O E_{t-1}$ is significantly positive in panel B with NASDAQ stocks, but turns negative in panel A with NYSE/AMEX stocks. For the growth option measure, the coefficients on $G O_{t-1}$ and $V G O_{t-1}$ are both significantly positive in panels A with NYSE/AMEX stocks, but lose their significance in most of the rows in panel B with NASDAQ stocks.

Next, we examine the performance of the overconfidence measures in these two types of markets. The coefficients on $T O_{t-1}$ and $M I S V_{t-1}$ are significantly positive in 
both panels. The coefficient on $S E N T_{t-1}^{\perp}$ is significant among NYSE/AMEX stocks at $1 \%$ level, but is insignificant among NASDAQ stocks.

Tables VIII and IX together suggest that the time-series relationship between overconfidence and the idiosyncratic risk is generally robust not only when controlling for the profitability and growth option measures, but also to the division of the sample based on age and exchange market. The power of the profitability and growth option measures, on the other hand, tends to be stronger among some stocks and weaker in others. It is desirable that further tests be conducted to confirm that these measures are not simply capturing the effects of some other variables. This could be a direction for future research.

\section{The Evolution of Overconfidence and the Time Pattern of Idiosyncratic Risk}

Tests in previous sections show that idiosyncratic risk is positively correlated with investor overconfidence at both the individual stock level and the market level. Figure 2 and unreported tests show that investor overconfidence increases significantly over the whole sample period, especially for the period before 2000 . The increasing time trend in idiosyncratic risk documented by Campbell et al. (2001) could therefore be partially driven by changes in investor overconfidence over time.

The increase in overconfidence is consistent with predictions made in studies on the evolution of overconfidence. Although studies in this research stream adopt 
various theoretical frameworks rooted in diverse intuitions, their conclusions are consistent: overconfident investors gain an evolutionary advantage.

Kyle and Wang (1997) posit that in a Cournot duopoly setting, overconfidence strictly dominates rationality, as overconfident investors have a reputation for trading aggressively, which intimidates rational or underconfident traders and leads them to trade less than optimally and make lower profits. Bernardo and Welch (2001) argue that overconfident investors are less likely to imitate their peers and more likely to explore the environment. Their trading activities then broadcast valuable information in their social group. As a result, a group with more overconfident investors gains an evolutionary advantage over groups with few such investors. Hirshleifer and Luo (2001) assert that overconfident traders are willing to take on more risks and hence are better than their rational counterparts at exploiting mispricing caused by liquidity or noise traders, and therefore persist in the market. Weinberg (2006) shows that moderately overestimating one's own ability leads a person to undertake challenging tasks more often, yielding higher expected output and utility. Weinberg states that it is reasonable to expect populations to evolve towards overconfidence, either because overconfident individuals with higher utility and output tend to have more offspring, or because younger generations become more overconfident by emulating successful individuals in the preceding generation.

However, it is worth noting that all the papers on the evolution of overconfidence mentioned previously stress that although overconfidence is advantageous and 
pervasive, it works to the advantage of overconfident investors only when their overconfidence level is moderately high. Investors with an extremely high level of overconfidence suffer, as they rely only on their own information and make mistakes too often (Bernardo and Welch, 2001), trade too aggressively and push price against them excessively (Hirshleifer and Luo, 2001), or undertake challenging tasks even when the expected output is low and lowers their expected utility (Weinberg, 2006).

Figure 1 shows that idiosyncratic risk, although manifesting an increasing trend over the whole sample period, decreased sharply after reaching a peak in 2000. The downward trend of idiosyncratic risk continues to the end of the sample period. Meanwhile, the three overconfidence measures in Figure 2 turn downwards at approximately the same time. The decrease in idiosyncratic risk and overconfidence lasts for years, and it seems difficult to attribute this decrease to simple time series fluctuations.

It is likely that investor overconfidence has accumulated to some extremely high level by the year 2000. The extremely high level of overconfidence leads investors to fail too frequently, and the cost of failures outweighs the benefits brought by overconfidence. The mass failures of these extremely overconfident investors in turn causes the market level of overconfidence to decrease. The drop in idiosyncratic risk after 2000 can be possibly explained by the decrease in overconfidence after that period. 


\section{Conclusion}

This paper tries to establish a link between investor overconfidence and idiosyncratic risk, and explain the time pattern of idiosyncratic risk from a behavioral perspective. "Overconfidence," describes the tendency of people to overestimate the sophistication of their skills. In the financial market, overconfidence is translated as the overestimation of investors of the precision of their private information. Daniel, Hirshleifer, and Subrahmanyam (1998) argue that overconfidence increases stock return volatility. Based on their work, we predict that overconfidence is positively correlated with idiosyncratic risk, and is partially responsible for the time pattern of idiosyncratic risk.

We use three proxies for overconfidence in this paper: investor sentiment, stock turnover, and stock misvaluation. Investor sentiment measures market conditions and could be a proxy for overconfidence, as previous studies suggest that overconfidence will be high following a bullish market. High stock turnover could be driven by heterogeneous beliefs promoted by overconfidence in one's own private information. Misvaluation is a direct result of overshooting by overconfident investors who overreact to their private information.

Cross-sectionally, we find that overconfidence is positively correlated with idiosyncratic risk. Controlling for some variables suggested by previous studies to be determinants of idiosyncratic risk, including firm age, size, stock price, profitability and growth option, does not affect the significance of the overconfidence measures. 
In time-series regressions, we find that after adding any of the three overconfidence proxies, the positive time trend in idiosyncratic risk is reduced or even redirected. To check the robustness of the results, we conduct multivariate tests controlling for both the profitability and growth option measures. Our overconfidence measures survive all tests. We also perform sub-sample tests based on age and exchange market, respectively. Overconfidence offers significant explanatory powers of the dynamics of idiosyncratic risk in all sub-samples.

Finally, we discuss the evolution of overconfidence over time and its relation with the time pattern of idiosyncratic risk. Both idiosyncratic risk and overconfidence increase significantly over the whole sample period, but decrease dramatically after 2000. The overall increasing trend in overconfidence is not surprising. Investors may become more overconfident as time passes as a result of the accumulation of investment expertise, the surge of information, or less credibility placed on public information. An increase in overconfidence is also consistent with the predictions in the literature of the evolution of overconfidence, which argue that overconfident investors can better survive as such investors more actively explore information, take on more challenging tasks, and increase group welfare. As the population evolves, more adaptable overconfident investors may dominate the market and increase market-level overconfidence.

However, research on the evolution of overconfidence also stresses that overconfidence is beneficial only when the level of overconfidence is not too high. Extremely 
high overconfidence may lead investors to fail too frequently, and the cost of overconfidence will exceed the benefits it brings. This may help to explain the dramatic and prolonged decrease in overconfidence after it hits a peak around 2000, and the subsequent decrease in idiosyncratic risk over the same period. 


\section{References}

Baker, Malcolm, and Jeffrey Wurgler, 2006, Investor Sentiment and the CrossSection of Stock Returns, The Journal of Finance 61, 1645-1680.

Barber, Brad M., and Terrance Odean, 2001, Boys Will Be Boys: Gender, Overconfidence, and Common Stock Investment, The Quarterly Journal of Economics 116, 261-292.

Benos, Alexandros V., 1998, Aggressiveness and Survival of Overconfident Traders, Journal of Financial Markets 1, 353-383.

Bernardo, Antonio E., and Ivo Welch, 2001, On the Evolution of Overconfidence and Entrepreneurs, Journal of Economics $\&$ Management Strategy 10, 301-330.

Black, Fischer, 1986, Noise, The Journal of Finance 41, 529-543.

Brandt, Michael W., Alon Brav, and John R. Graham, 2005, The Idiosyncratic Volatility Puzzle: Time Trend or Speculative Episodes?, Working paper, Duke University.

Caballe, Jordi, and Jozsef Sakovics, 2003, Speculating Against an Overconfident Market, Journal of Financial Markets 6, 199-225.

Campbell, John Y., Martin Lettau, Burton G. Malkiel, and Yexiao Xu, 2001, Have Individual Stocks Become More Volatile? An Empirical Exploration of Idiosyncratic Risk, The Journal of Finance 56, 1-43. 
Cao, Charles, Timothy Simin, and Jing Zhao, 2007, Can Growth Options Explain the Trend in Idiosyncratic Risk?, The Review of Financial Studies, forthcoming.

Daniel, Kent, David Hirshleifer, and Avanidhar Subrahmanyam, 1998, Investor Psychology and Security Market Under- and Overreactions, The Journal of Finance 53, 1839-1885.

Daniel, Kent D., David Hirshleifer, and Avanidhar Subrahmanyam, 2001, Overconfidence, Arbitrage, and Equilibrium Asset Pricing, The Journal of Finance 56, 921-965.

Gervais, Simon, and Terrance Odean, 2001, Learning To Be Overconfident, The Review of Financial Studies 14, 1-27.

Hirshleifer, David, and Guo Ying Luo, 2001, On the Survival of Overconfident Traders in a Competitive Securities Market, Journal of Financial Markets 4, 73-84.

Kyle, Albert S., and F. Albert Wang, 1997, Speculation Duopoly with Agreement to Disagree: Can Overconfidence Survive the Market Test?, The Journal of Finance 52, 2073-2090.

Meir, Statman, Steven Thorley, and Keith Vorkink, 2006, Investor Overconfidence and Trading Volume, The Review of Financial Studies 19, 1531.

Odean, Terrance, 1998, Volume, Volatility, Price, and Profit When All Traders Are Above Average, The Journal of Finance 53, 1887-1934. 
Pastor, Lubos, and Pietro Veronesi, 2003, Stock Valuation and Learning about Profitability, The Journal of Finance 58, 1749-1789.

Rhodes-Kropf, Matthew, David T. Robinson, and S. Viswanathan, 2005, Valuation Waves and Merger Activity: The Empirical Evidence, Journal of Financial Economics 77, 561-603.

Roll, Richard, 1988, $R^{2}$, The Journal of Finance 43, 541-566.

Scheinkman, Jose A., and Wei Xiong, 2003, Overconfidence and Speculative Bubbles, The Journal of Political Economy 111, 1183-1219.

Shiller, Robert J., 1981, Do Stock Prices Move Too Much to be Justified by Subsequent Changes in Dividends?, The American Economic Review 71, 421-436.

Shiller, Robert J., 2000. Irrational Exuberance, Princeton University Press, Princeton.

Wei, Steven X., and Chu Zhang, 2006, Why Did Individual Stocks Become More Volatile?, The Journal of Business 79, 259-292.

Weinberg, B. A., 2006, A Model of Overconfidence, Working paper, Ohio State University.

Xu, Yexiao, and Burton G. Malkiel, 2003, Investigating the Behavior of Idiosyncratic Volatility, The Journal of Business 76, 613-644. 
Figure 1. Time trend of idiosyncratic risk. This figure plots the time series of idiosyncratic risk, $V_{t}$, which is calculated based on beta free method.

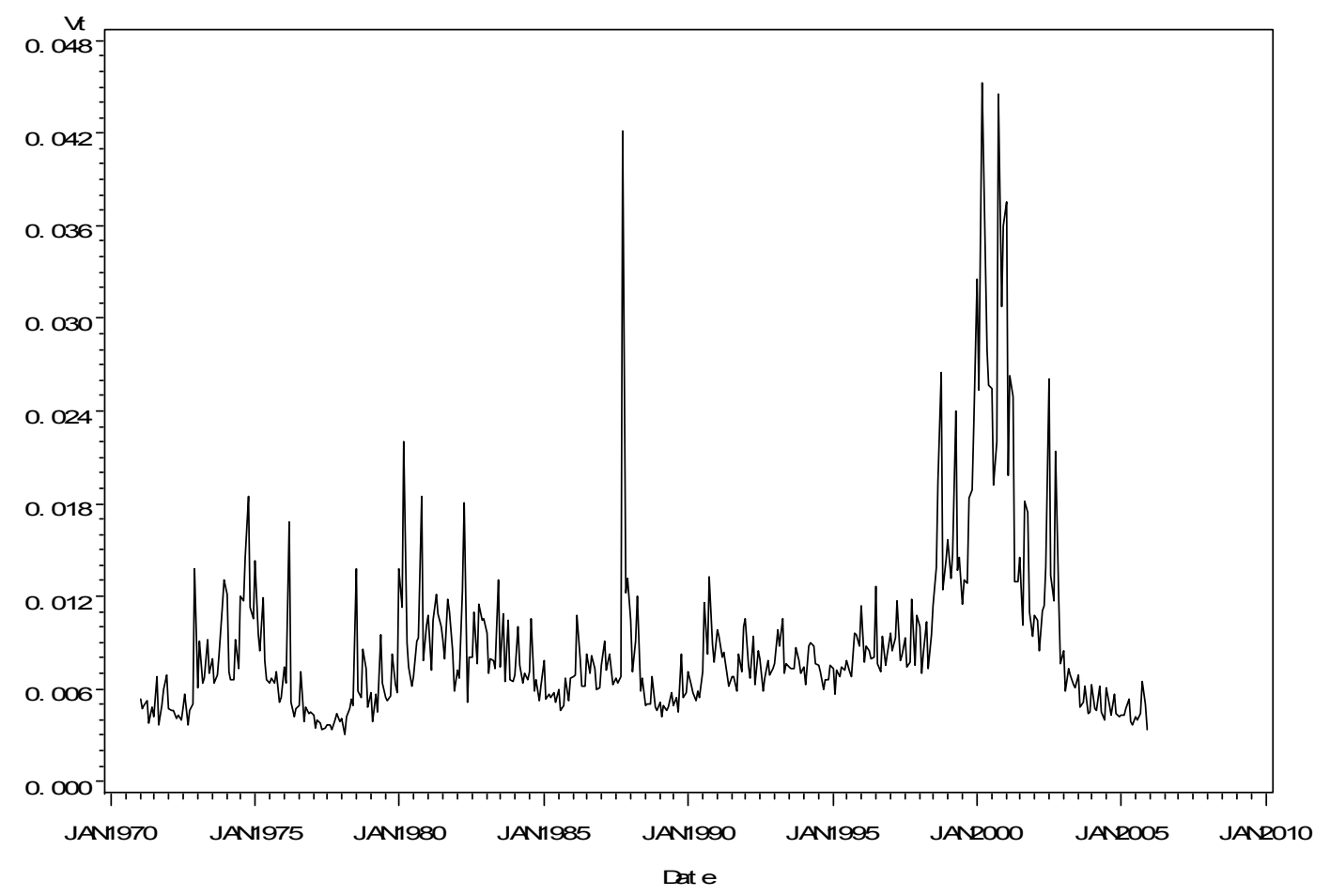


Figure 2. Time trend of investor overconfidence measures. This figure plots the time series of overconfidence measures. Figures 2(a), 2(b) and 2(c) present time trends of investor sentiment index, stock turnover, and stock misvaluation, respectively.

Figure 2(a): Investor sentiment

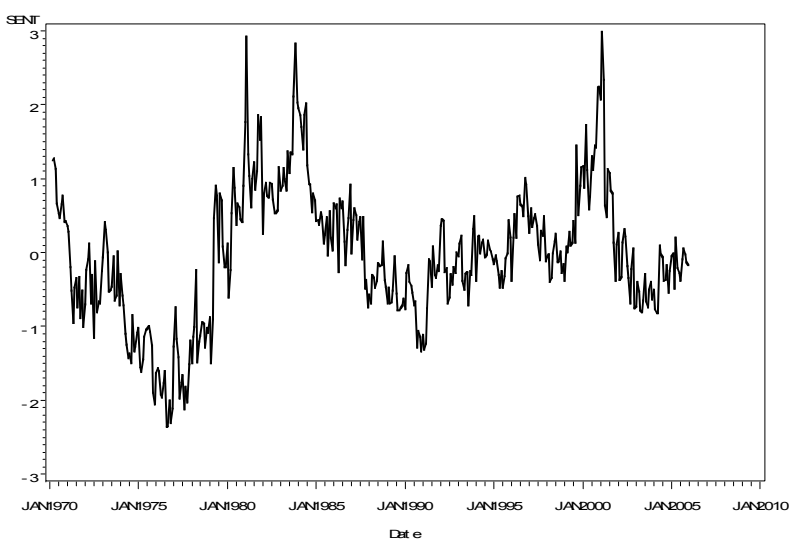

Figuire 2(b): Stock Turinover

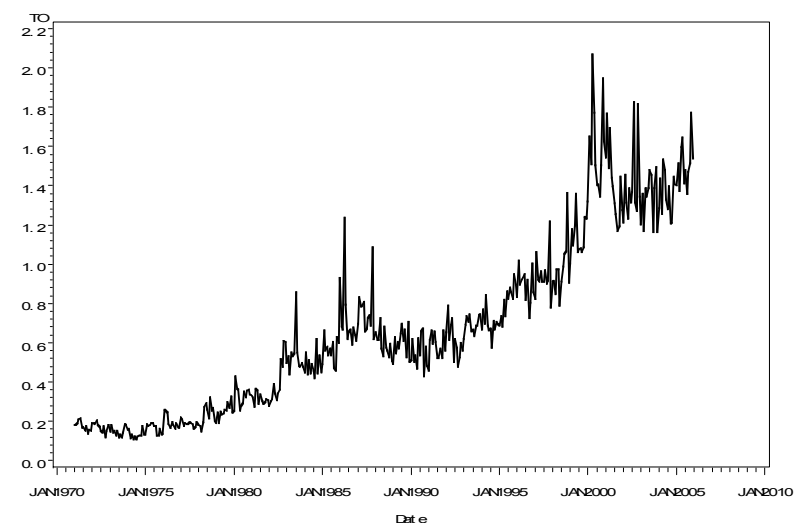

Figure 2(c): Stock ivisvaluation

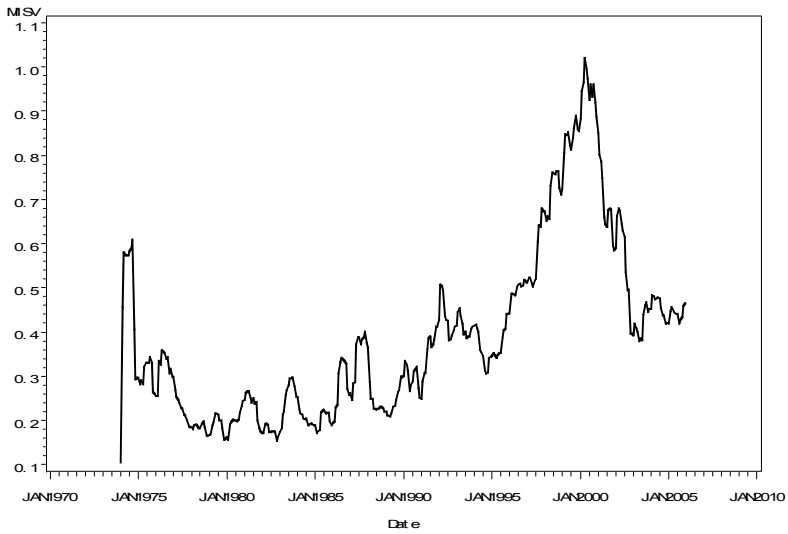


Figure 3. Idiosyncratic risk of young and old firms. This figure plots the time series of idiosyncratic risk, $V_{t}$, of young and old firms, respectively. The solid line and dashed line represent idiosyncratic risk of old and young firms, respectively.

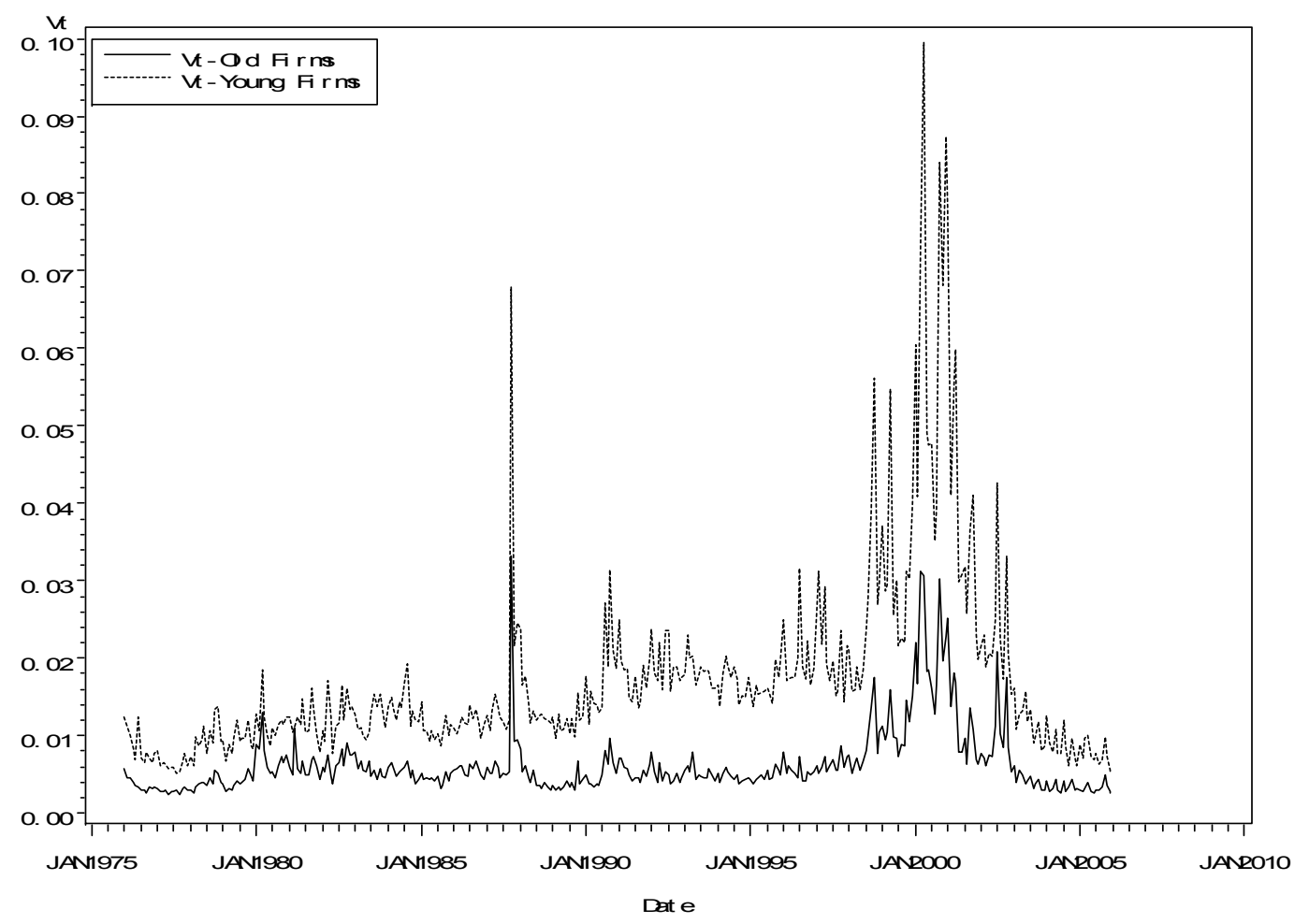


Figure 4. Overconfidence towards young and old firms. This figure plots the time series of stock turnover, $T O_{t-1}$, and misvaluation, $M I S V_{t-1}$, of young and old firms. The unbold solid line and unbold dashed line represent stock turnover of old and young firms, respectively. The bold solid line and bold dashed line represent stock misvaluation of old and young firms, respectively.

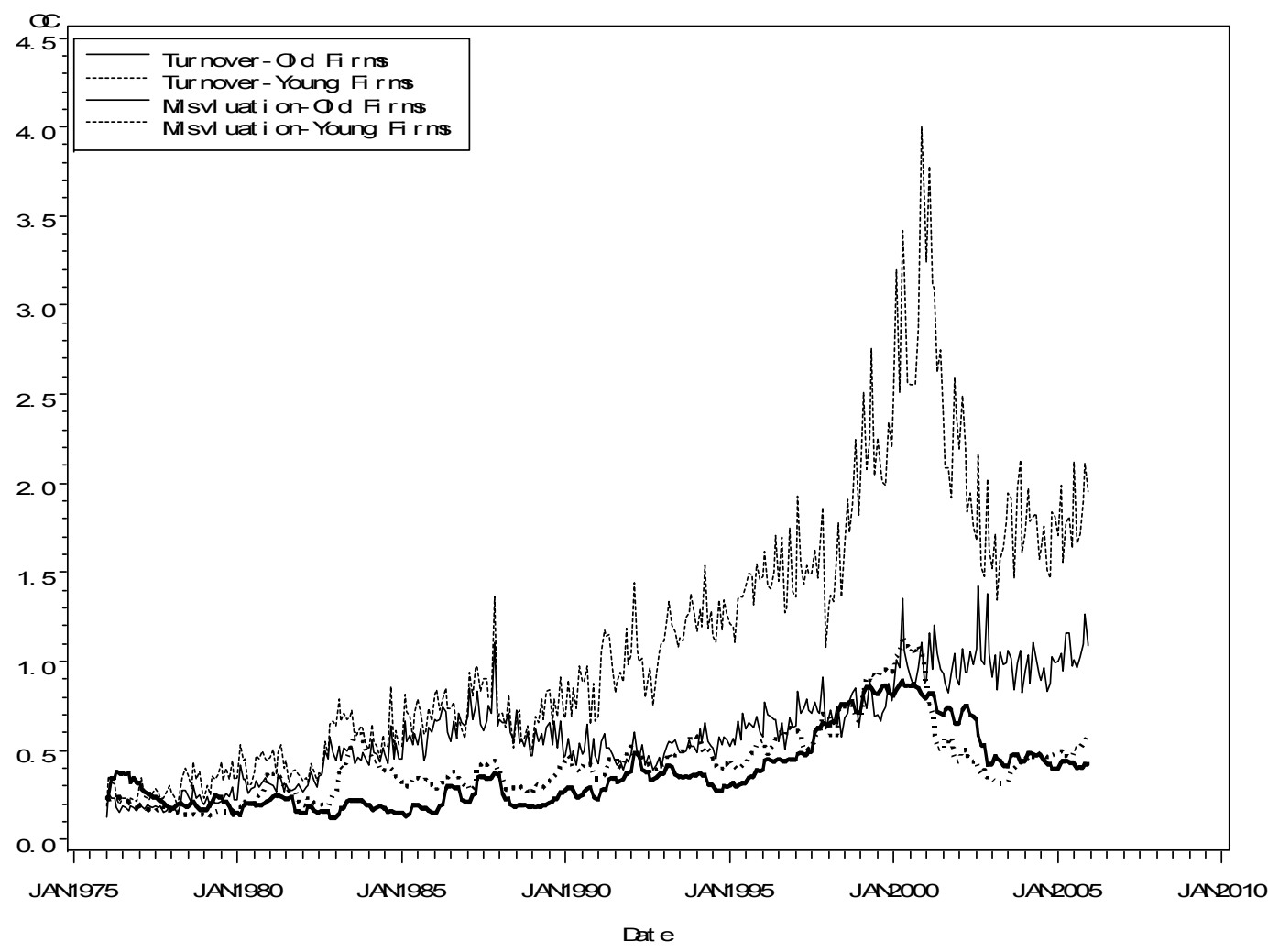




\section{Table I: Summary Statistics}

$V_{t}$ is the monthly value-weighted idiosyncratic risk of individual stocks in month $t$, based on stocks' market capitalizations at the end of the previous month. $V_{t}$ is calculated based on the beta free method, which is described in section I.A. $S E N T_{t}^{\perp}$ is the monthly investor sentiment index taken from Jeffrey Wurgler's homepage. $T O_{t}$ is the monthly value-weighted stock turnover. $M I S V_{t}$ is the value-weighted misvaluation of stocks. $S I Z E_{i, t}$ denotes market capitalization of firm $i$ at month $t$. $R O E_{t}$ is the value-weighted return on equity. $(M / B)_{t}$ is the value-weighted market value to book value ratio. $(M / V)_{t}$ is the component of $(M / B)_{t}$ that captures the misvaluation of firms, and $(V / B)_{t}$ is the component of $(M / B)_{t}$ that denotes the growth option. $V R O E_{t},(V M / B)_{t},(V V / B)_{t}$, and $(V M / V)_{t}$ are the time-series variances of the corresponding measures based on data in the previous 36 months. All accounting data are winsorized at the $2.5 \%$ level at the head and tail.

Table I(a): Summary Statistics of Idiosyncratic Risk

\begin{tabular}{ccccccc}
\hline \multicolumn{7}{c}{$V_{t}$} \\
\hline Periods & $(1)$ No. of Obs. & $(2)$ Mean & $(3)$ Median & (4) Std. & (5) Skewness & (6) Kurtosis \\
\hline $1971-1975$ & 248681 & 0.0074 & 0.0066 & 0.0032 & 1.2654 & 1.3224 \\
$1976-1980$ & 293659 & 0.0066 & 0.0054 & 0.0038 & 2.2314 & 5.5013 \\
$1981-1985$ & 347426 & 0.0081 & 0.0074 & 0.0026 & 1.1894 & 2.1436 \\
$1986-1990$ & 410113 & 0.0076 & 0.0067 & 0.0050 & 5.7084 & 38.6588 \\
$1991-1995$ & 445805 & 0.0077 & 0.0074 & 0.0012 & 0.6288 & -0.2521 \\
$1996-2000$ & 524257 & 0.0158 & 0.0118 & 0.0103 & 1.7554 & 2.8781 \\
$2001-2005$ & 423894 & 0.0093 & 0.0062 & 0.0069 & 2.0126 & 4.5164 \\
All & 2693835 & 0.0089 & 0.0073 & 0.0062 & 3.3741 & 14.8656 \\
\hline
\end{tabular}


Table I(b): Summary Statistics of Overconfidence Measures, Profitability, and $M / B$ Ratio with its Components

\begin{tabular}{|c|c|c|c|c|c|c|}
\hline \multicolumn{7}{|c|}{ Panel A - Overconfidence Measures } \\
\hline \multirow[b]{2}{*}{ Periods } & \multicolumn{2}{|c|}{ (1) $S E N T_{t}^{\perp}$} & \multicolumn{2}{|c|}{ (2) $T O_{t}$} & \multicolumn{2}{|c|}{ (3) $M I S V_{t}$} \\
\hline & $\begin{array}{l}\text { Mean of } \\
S E N T_{t}^{\perp}\end{array}$ & $\begin{array}{c}\text { Median of } \\
S E N T_{t}^{\perp}\end{array}$ & $\begin{array}{c}\text { Mean of } \\
T O_{t}\end{array}$ & $\begin{array}{c}\text { Median of } \\
T O_{t}\end{array}$ & $\begin{array}{l}\text { Mean of } \\
M I S V_{t}\end{array}$ & $\begin{array}{c}\text { Median of } \\
M I S V_{t} \\
\end{array}$ \\
\hline $1971-1975$ & -0.7102 & -0.6947 & 0.1572 & 0.1546 & - & - \\
\hline $1976-1980$ & -0.8285 & -1.1118 & 0.2419 & 0.2411 & 0.2243 & 0.2007 \\
\hline 1981-1985 & 1.0414 & 0.9321 & 0.4699 & 0.4787 & 0.2080 & 0.2009 \\
\hline $1986-1990$ & -0.2229 & -0.3600 & 0.6392 & 0.6209 & 0.2821 & 0.2702 \\
\hline 1991-1995 & -0.1770 & -0.1650 & 0.6847 & 0.6830 & 0.3899 & 0.3919 \\
\hline $1996-2000$ & 0.4895 & 0.3933 & 1.1179 & 1.0107 & 0.7244 & 0.7383 \\
\hline $2001-2005$ & -0.0503 & -0.2142 & 1.4003 & 1.3877 & 0.5122 & 0.4594 \\
\hline All & -0.0654 & -0.1117 & 0.6730 & 0.6045 & 0.3902 & 0.3463 \\
\hline \multicolumn{7}{|c|}{ Panel B - SIZE and ROE } \\
\hline & \multicolumn{2}{|c|}{ (1) $S I Z E_{i, t}$} & \multicolumn{2}{|c|}{ (2) $R O E_{t}$} & \multicolumn{2}{|c|}{ (3) $V R O E_{t}$} \\
\hline Periods & $\begin{array}{l}\text { Mean of } \\
S I Z E_{i, t} \\
\end{array}$ & $\begin{array}{c}\text { Median of } \\
S I Z E_{i, t} \\
\end{array}$ & $\begin{array}{l}\text { Mean of } \\
R O E_{t}\end{array}$ & $\begin{array}{c}\text { Median of } \\
R O E_{t}\end{array}$ & $\begin{array}{l}\text { Mean of } \\
V R O E_{t}\end{array}$ & $\begin{array}{c}\text { Median of } \\
V R O E_{t}\end{array}$ \\
\hline $1971-1975$ & 209327 & 20676 & - & - & - & - \\
\hline 1976-1980 & 211721 & 24306 & 0.0433 & 0.0431 & 0.0004 & 0.0004 \\
\hline $1981-1985$ & 301288 & 34337 & 0.0384 & 0.0379 & 0.0010 & 0.0011 \\
\hline $1986-1990$ & 425106 & 38747 & 0.0396 & 0.0406 & 0.0024 & 0.0025 \\
\hline $1991-1995$ & 638126 & 67022 & 0.0432 & 0.0434 & 0.0029 & 0.0030 \\
\hline $1996-2000$ & 1411761 & 117012 & 0.0503 & 0.0502 & 0.0041 & 0.0039 \\
\hline $2001-2005$ & 2049038 & 187234 & 0.0405 & 0.0420 & 0.0044 & 0.0044 \\
\hline All & 848763 & 60332 & 0.0426 & 0.0426 & 0.0025 & 0.0028 \\
\hline \multicolumn{7}{|c|}{ Panel $\mathrm{C}-M / B$ and its Components } \\
\hline & \multicolumn{2}{|c|}{$(1)(M / B)_{t}$} & \multicolumn{2}{|c|}{$(2)(V / B)_{t}$} & \multicolumn{2}{|c|}{$(3)(M / V)_{t}$} \\
\hline Periods & $\begin{array}{l}\text { Mean of } \\
(M / B)_{t}\end{array}$ & $\begin{array}{l}\text { Mean of } \\
(V M / B)_{t}\end{array}$ & $\begin{array}{l}\text { Mean of } \\
(V / B)_{t}\end{array}$ & $\begin{array}{l}\text { Mean of } \\
(V V / B)_{t}\end{array}$ & $\begin{array}{l}\text { Mean of } \\
(M / V)_{t}\end{array}$ & $\begin{array}{l}\text { Mean of } \\
(V M / V)_{t}\end{array}$ \\
\hline $1976-1980$ & 1.4604 & 0.0864 & 1.3636 & 0.0090 & 1.0469 & 0.0255 \\
\hline $1981-1985$ & 1.4854 & 0.0895 & 1.3693 & 0.0278 & 1.0650 & 0.0253 \\
\hline $1986-1990$ & 1.7486 & 0.1109 & 1.3968 & 0.0480 & 1.2221 & 0.0319 \\
\hline 1991-1995 & 2.1007 & 0.1680 & 1.4721 & 0.0565 & 1.3599 & 0.0362 \\
\hline $1996-2000$ & 3.1251 & 0.3769 & 1.6202 & 0.0833 & 1.7087 & 0.0592 \\
\hline 2001-2005 & 2.3798 & 0.4353 & 1.5071 & 0.0963 & 1.4849 & 0.0641 \\
\hline All & 2.0500 & 0.2112 & 1.4549 & 0.0535 & 1.3146 & 0.0404 \\
\hline
\end{tabular}


Table II: Idiosyncratic Risk, $M / B$ Ratio, and M/B Components

For each month, $(M / B)_{i, t}$ is calculated following Cao et al. (2007). It is then decomposed to get $(V / B)_{i, t}$ and $(M / V)_{i, t}$. The methodology for decomposition is described in section I.A. The ratios $(M / B)_{i, t},(V / B)_{i, t}$, and $(M / V)_{i, t}$ are value weighted monthly to get $(M / B)_{t},(V / B)_{t}$ and $(M / V)_{t}$, respectively. $(V M / B)_{t}$, $(V V / B)_{t}$ and $(V M / V)_{t}$ are the value-weighted time-series variances of $(M / B)_{i, t}$, $(V / B)_{i, t}$ and $(M / V)_{i, t}$, respectively, based on data in the previous 36 months. Firm months with fewer than nine observations in the previous three years are deleted. The monthly value-weighted idiosyncratic risk, $V_{t}$, is regressed on a time trend measure $t$, and $(M / B)_{t-1},(V / B)_{t-1}$ and $(M / V)_{t-1}$, respectively. Data cover the period from $01 / 1976$ to $12 / 2005$. The numbers in parentheses are $t$-ratios based on Newy-West standard errors with 12-month lags. ***, **, and * denote significance at the $1 \%$, $5 \%$, and $10 \%$ level, respectively.

\begin{tabular}{|c|c|c|c|c|c|}
\hline & Intercept & $t$ & & & Adj. $R^{2}$ \\
\hline \multirow[t]{2}{*}{ (1) } & $\begin{array}{c}0.004672^{* * *} \\
(4.54)\end{array}$ & $\begin{array}{c}0.000020^{* *} \\
(2.14)\end{array}$ & & & 0.1218 \\
\hline & Intercept & $t$ & $(M / B)_{t-1}$ & $(V M / B)_{t-1}$ & Adj. $R^{2}$ \\
\hline \multirow[t]{2}{*}{ (2) } & $\begin{array}{c}-0.004300^{* *} \\
(-2.00)\end{array}$ & $\begin{array}{c}-0.000030^{* * * *} \\
(-2.85)\end{array}$ & $\begin{array}{c}0.007534^{* * *} \\
(5.37)\end{array}$ & $\begin{array}{c}0.009428^{*} \\
(1.85)\end{array}$ & 0.5659 \\
\hline & Intercept & $t$ & $(V / B)_{t-1}$ & $(V V / B)_{t-1}$ & Adj. $R^{2}$ \\
\hline \multirow[t]{2}{*}{ (3) } & $\begin{array}{c}-0.046830^{* * *} \\
(-4.92)\end{array}$ & $\begin{array}{c}-0.000030^{* * * *} \\
(-6.57)\end{array}$ & $\begin{array}{c}0.038950^{* * * *} \\
(5.45)\end{array}$ & $\begin{array}{c}0.088895^{* * *} \\
(5.25)\end{array}$ & 0.5800 \\
\hline & Intercept & $t$ & $(M / V)_{t-1}$ & $(V M / V)_{t-1}$ & Adj. $R^{2}$ \\
\hline (4) & $\begin{array}{c}-0.015150^{* * * *} \\
(-2.85)\end{array}$ & $\begin{array}{c}-0.000030^{* *} \\
(-2.03)\end{array}$ & $\begin{array}{c}0.019791^{* * *} \\
(3.93)\end{array}$ & $\begin{array}{c}0.059357 \\
(0.99)\end{array}$ & 0.4543 \\
\hline
\end{tabular}




\section{Table III: Idiosyncratic Risk and Investor Overconfidence: Cross-Sectional Tests}

For each month between $01 / 1976$ and $12 / 2005$, idiosyncratic risk, $V_{i, t}$, is cross-sectionally regressed on overconfidence measures and some control variables. $R E T_{i, t}$ is the stock return. $S I Z E_{i, t}$ is the $\log$ of the market capitalization of firm $i$. $L E V_{i, t}$ is the leverage ratio calculated by dividing total liabilities by total assets. $A G E_{i, t}$ is the $\log$ of the number of years since firm $i$ 's first appearance in the CRSP. $P R C_{i, t}$ is the stock price. $R O E_{i, t}$ is the return on equity. $(M / B)_{i, t}$ is the market value to book value ratio. $G O_{i, t}$ measures the long-term growth option and is free of the influence of misvaluation. $T O_{i, t}$ is the stock turnover. $M I S V_{i, t}$ is the misvaluation of firm $i$ 's stock. $V R O E_{i, t},(V M / B)_{i, t}$, and $V G O_{i, t}$ are time-series variances of the corresponding measures based on data in the previous 36 months. The averages of the estimated coefficients over the whole sample period are multiplied by 100 and reported. The numbers in parentheses are $t$-ratios based on the time-series means and standard errors of the estimated coefficients. ${ }^{* *},{ }^{* *}$, and $*$ denote significance at the $1 \%, 5 \%$, and $10 \%$ level, respectively.

$V_{i, t}=\beta_{0}+\beta_{1} R E T_{i, t-1}+\beta_{2} S I Z E_{i, t-1}+\beta_{3} L E V_{i, t-1}+\beta_{4} A G E_{i, t}+\beta_{5} P R C_{i, t-1}+\beta_{6} R O E_{i, t-1}+\beta_{7} V R O E_{i, t-1}+\beta_{8} G O_{i, t-1}+$ $\beta_{9} V G O_{i, t-1}+\beta_{10} O C_{i, t-1}+\epsilon_{i, t}$.

\begin{tabular}{|c|c|c|c|c|c|c|c|c|c|c|}
\hline & $(1)$ & $(2)$ & $(3)$ & $(4)$ & $(5)$ & $(6)$ & $(7)$ & $(8)$ & $(9)$ & $(10)$ \\
\hline Intercept & $\begin{array}{c}0.8443^{* * *} \\
(26.86)\end{array}$ & $\begin{array}{c}0.7399^{* * * *} \\
(26.55)\end{array}$ & $\begin{array}{c}0.8247^{* * * *} \\
(26.88)\end{array}$ & $\begin{array}{c}0.6878^{* * *} \\
(26.38)\end{array}$ & $\begin{array}{c}0.8474^{* * *} \\
(27.23)\end{array}$ & $\begin{array}{c}0.7877^{* * * *} \\
(26.61)\end{array}$ & $\begin{array}{c}0.7324^{* * * *} \\
(25.95)\end{array}$ & $\begin{array}{c}0.6783^{* * *} \\
(25.60)\end{array}$ & $\begin{array}{c}0.6352^{* * *} \\
(25.07)\end{array}$ & $\begin{array}{c}0.6142^{* * * *} \\
(24.66)\end{array}$ \\
\hline$R E T_{i, t-1}$ & $\begin{array}{c}-0.1984^{* * *} \\
(-10.63)\end{array}$ & $\begin{array}{c}-0.1868^{* * *} \\
(-10.54)\end{array}$ & $\begin{array}{c}-0.1947^{* * *} \\
(-10.58)\end{array}$ & $\begin{array}{c}-0.2019^{* * *} \\
(-11.19)\end{array}$ & $\begin{array}{c}-0.2074^{* * *} \\
(-11.24)\end{array}$ & $\begin{array}{c}-0.1987 * * * \\
(-10.90)\end{array}$ & $\begin{array}{c}-0.1915^{* * *} \\
(-10.80)\end{array}$ & $\begin{array}{c}-0.1913^{* * *} \\
(-10.82)\end{array}$ & $\begin{array}{c}-0.1952^{* * *} \\
(-11.20)\end{array}$ & $\begin{array}{c}-0.1896^{* * * *} \\
(-10.92)\end{array}$ \\
\hline$S I Z E_{i, t-1}$ & $\begin{array}{c}-0.0598^{* * *} * \\
(-25.03)\end{array}$ & $\begin{array}{c}-0.0523^{* * *} \\
(-24.41)\end{array}$ & $\begin{array}{c}-0.0615^{* * *} \\
(-26.18)\end{array}$ & $\begin{array}{c}-0.0543^{* * *} * \\
(-26.07)\end{array}$ & $\begin{array}{c}-0.0614^{* * *} * \\
(-25.88)\end{array}$ & $\begin{array}{c}-0.0603 * * * \\
(-25.08)\end{array}$ & $\begin{array}{c}-0.0527^{* * *} * \\
(-24.59)\end{array}$ & $\begin{array}{c}-0.0488^{* * *} \\
(-23.93)\end{array}$ & $\begin{array}{c}-0.1952^{* * *} \\
(-11.20)\end{array}$ & $\begin{array}{c}-0.0500^{* * *} \\
(-23.88)\end{array}$ \\
\hline$L E V_{i, t-1}$ & $\begin{array}{c}0.0069 \\
(1.02)\end{array}$ & $\begin{array}{c}-0.0186^{* * * *} \\
(-2.66)\end{array}$ & $\begin{array}{c}0.0404^{* * * *} \\
(6.32)\end{array}$ & $\begin{array}{c}0.0718^{* * * *} \\
(11.48)\end{array}$ & $\begin{array}{c}0.0117^{*} \\
(1.74)\end{array}$ & $\begin{array}{c}0.0596^{* * * *} \\
(9.41)\end{array}$ & $\begin{array}{c}-0.0084 \\
(-1.27)\end{array}$ & $\begin{array}{c}0.0141^{* *} \\
(2.24)\end{array}$ & $\begin{array}{c}0.0410 * * * \\
(6.60)\end{array}$ & $\begin{array}{c}0.0683^{* * * *} \\
(10.81)\end{array}$ \\
\hline$A G E_{i, t}$ & $\begin{array}{c}-0.0070^{* * *} \\
(-8.12)\end{array}$ & $\begin{array}{c}-0.0017^{* *} \\
(-2.15)\end{array}$ & $\begin{array}{c}-0.0005 \\
(-0.68)\end{array}$ & $\begin{array}{c}-0.0014 \\
(-1.57)\end{array}$ & $\begin{array}{c}-0.0048^{* * *} \\
(-5.82)\end{array}$ & $\begin{array}{c}-0.0028^{* * *} \\
(-3.39)\end{array}$ & $\begin{array}{c}0.0012 \\
(1.62)\end{array}$ & $\begin{array}{c}-0.0007 \\
(-1.04)\end{array}$ & $\begin{array}{c}0.0024 * * * \\
(2.91)\end{array}$ & $\begin{array}{c}0.0030^{* * * *} \\
(3.54)\end{array}$ \\
\hline$P R C_{i, t-1}$ & $\begin{array}{c}-0.0001^{* * *} \\
(-6.77)\end{array}$ & & & & & & $\begin{array}{c}-0.0001^{* * *} \\
(-7.46)\end{array}$ & $\begin{array}{c}-0.0001^{* * *} \\
(-7.82)\end{array}$ & $\begin{array}{c}-0.0001^{* * *} \\
(-6.60)\end{array}$ & $\begin{array}{c}-0.0001^{* * *} \\
(-6.98)\end{array}$ \\
\hline$R O E_{i, t-1}$ & & $\begin{array}{c}-0.3724^{* * *} \\
(-22.05)\end{array}$ & & & & & $\begin{array}{c}-0.3597^{* * * *} \\
(-21.78)\end{array}$ & $\begin{array}{c}-0.3600^{* * *} \\
(-21.82)\end{array}$ & $\begin{array}{c}-0.3285^{* * *} \\
(-21.13)\end{array}$ & $\begin{array}{c}-0.3284^{* * *} \\
(-21.10)\end{array}$ \\
\hline$V R O E_{i, t-1}$ & & $\begin{array}{c}1.4829^{* * * *} \\
(23.22)\end{array}$ & & & & & $\begin{array}{c}1.4056^{* * * *} \\
(21.80)\end{array}$ & $\begin{array}{c}1.4283^{* * *} \\
(21.98)\end{array}$ & $\begin{array}{c}1.0264^{* * *} * \\
(15.94)\end{array}$ & $\begin{array}{c}0.9781^{* * * *} \\
(15.41)\end{array}$ \\
\hline$(M / B)_{i, t-1}$ & & & $\begin{array}{c}0.0063^{* * *} \\
(8.39)\end{array}$ & & & & $\begin{array}{c}-0.0020^{* * *} \\
(-2.23)\end{array}$ & $\begin{array}{c}-0.0207^{* * *} \\
(-12.78)\end{array}$ & & \\
\hline$(V M / B)_{i, t-1}$ & & & $\begin{array}{c}0.0303^{* * * *} \\
(20.70)\end{array}$ & & & & $\begin{array}{c}0.0181^{* * *} * \\
(14.19)\end{array}$ & $\begin{array}{c}0.0186^{* * *} \\
(14.36)\end{array}$ & & \\
\hline$G O_{i, t-1}$ & & & & $\begin{array}{c}0.0379 * * * \\
(19.43)\end{array}$ & & & & & $\begin{array}{c}0.0340^{* * *} \\
(16.57)\end{array}$ & $\begin{array}{c}0.0303^{* * *} \\
(15.28)\end{array}$ \\
\hline$V G O_{i, t-1}$ & & & & $\begin{array}{c}0.0024^{*} \\
(1.92)\end{array}$ & & & & & $\begin{array}{c}-0.0076^{* * *} \\
(-5.52)\end{array}$ & $\begin{array}{c}-0.0072^{* * * *} \\
(-5.36)\end{array}$ \\
\hline$T O_{i, t-1}$ & & & & & $\begin{array}{c}0.0126^{* * *} \\
(12.63)\end{array}$ & & $\begin{array}{c}0.0091^{* * *} \\
(9.73)\end{array}$ & & $\begin{array}{c}0.0086^{* * * *} \\
(9.01)\end{array}$ & \\
\hline$M I S V_{i, t-1}$ & & & & & & $\begin{array}{c}0.1357^{* * *} \\
(23.21)\end{array}$ & & $\begin{array}{c}0.1454^{* * *} \\
(20.39)\end{array}$ & & $\begin{array}{c}0.0905^{* * *} \\
(22.35)\end{array}$ \\
\hline Adj.R $R^{2}$ & 0.0870 & 0.1092 & 0.0925 & 0.1059 & 0.0903 & 0.0949 & 0.1150 & 0.1188 & 0.1267 & 0.1274 \\
\hline
\end{tabular}




\section{Table IV: Cross-Sectional Tests in Subsamples}

For each month between 01/1976 and 12/2005, stocks are sorted from low to high based on their size, age, or stock price, separately. Stocks in the lowest and highest thirtieth percentiles are classified as Low (L) and High (H), respectively. Stocks in the middle fortieth percentile are classified as Medium (M). Within each subgroup, idiosyncratic risk, $V_{i, t}$, is cross-sectionally regressed on overconfidence measures and some control variables. The averages of the estimated coefficients for each fiver-year-subperiod are multiplied by 100 and reported. The numbers in parentheses are $t$-ratios based on the time-series means and standard errors of the estimated coefficients. ${ }^{* *}, * *$, and $*$ denote significance at the $1 \%, 5 \%$, and $10 \%$ level, respectively.

$V_{i, t}=\beta_{0}+\beta_{1} R E T_{i, t-1}+\beta_{2} S I Z E_{i, t-1}+\beta_{3} L E V_{i, t-1}+\beta_{4} A G E_{i, t}+\beta_{5} P R C_{i, t-1}+\beta_{6} R O E_{i, t-1}+\beta_{7} V R O E_{i, t-1}+\beta_{8} G O_{i, t-1}+$ $\beta_{9} V G O_{i, t-1}+\beta_{10} O C_{i, t-1}+\epsilon_{i, t}$.

\begin{tabular}{|c|c|c|c|c|c|c|c|c|c|c|c|c|}
\hline & Intercept & $R E T_{i, t-1}$ & $S I Z E_{i, t-1}$ & $L E V_{i, t-1}$ & $A G E_{i, t}$ & $P R C_{i, t-1}$ & $R O E_{i, t-1}$ & $V R O E_{i, t-1}$ & $G O_{i, t-1}$ & $V G O_{i, t-1}$ & $O C_{i, t-1}$ & Adj. $R^{2}$ \\
\hline \multicolumn{13}{|c|}{ Panel A: Subsample Tests Based on Size, $O C_{i, t-1}=T O_{i, t-1}$} \\
\hline (1)L & $\begin{array}{c}0.0141^{* * *} \\
(12.44) \\
\end{array}$ & $\begin{array}{c}-0.0020^{* * *} \\
(-20.38) \\
\end{array}$ & $\begin{array}{c}-0.0021^{* * *} \\
(-9.27)\end{array}$ & $\begin{array}{c}-0.0009^{* * *} \\
(-8.52) \\
\end{array}$ & $\begin{array}{c}0.0003^{*} \\
(1.66) \\
\end{array}$ & $\begin{array}{c}-0.0002^{* * *} \\
(-8.05) \\
\end{array}$ & $\begin{array}{c}-0.0021^{* * *} \\
(-8.84) \\
\end{array}$ & $\begin{array}{c}0.0052^{* * *} \\
(4.32) \\
\end{array}$ & $\begin{array}{c}0.0001^{* * *} \\
(4.72) \\
\end{array}$ & $\begin{array}{c}-0.0001^{* * *} \\
(-2.69) \\
\end{array}$ & $\begin{array}{c}0.0003^{* * *} \\
(8.14) \\
\end{array}$ & 0.1629 \\
\hline (2)M & $\begin{array}{c}0.0030 * * * \\
(30.04) \\
\end{array}$ & $\begin{array}{c}-0.0006^{* * *} \\
(-27.10) \\
\end{array}$ & $\begin{array}{c}-0.0002^{* * *} \\
(-3.57) \\
\end{array}$ & $\begin{array}{c}-0.0001^{* * *} \\
(-7.71) \\
\end{array}$ & $\begin{array}{c}-0.0002^{* * *} \\
(-3.96) \\
\end{array}$ & $\begin{array}{c}-0.0001^{* * *} \\
(-10.02) \\
\end{array}$ & $\begin{array}{c}-0.0009^{* * *} \\
(-13.57) \\
\end{array}$ & $\begin{array}{c}0.0037^{* * *} \\
(14.93) \\
\end{array}$ & $\begin{array}{c}0.0001^{* * *} \\
(8.88) \\
\end{array}$ & $\begin{array}{l}0.0000 \\
(-0.65) \\
\end{array}$ & $\begin{array}{c}0.0001^{* * *} \\
(22.11) \\
\end{array}$ & 0.1761 \\
\hline$(3) \mathrm{H}$ & $\begin{array}{c}0.0011^{* * *} \\
(36.03) \\
\end{array}$ & $\begin{array}{c}-0.0002^{* * *} \\
(-16.60) \\
\end{array}$ & $\begin{array}{c}-0.0003^{* * *} \\
(-4.55) \\
\end{array}$ & $\begin{array}{c}0.0000^{* * *} \\
(-7.99) \\
\end{array}$ & $\begin{array}{c}-0.0001^{* * *} \\
(-6.53) \\
\end{array}$ & $\begin{array}{c}0.0000 * * * \\
(-14.88) \\
\end{array}$ & $\begin{array}{c}-0.0005^{* * *} \\
(-10.74) \\
\end{array}$ & $\begin{array}{c}0.0047^{* * *} \\
(7.77) \\
\end{array}$ & $\begin{array}{c}0.0001^{* * *} \\
(23.29) \\
\end{array}$ & $\begin{array}{c}-0.0001^{* * *} \\
(-3.43) \\
\end{array}$ & $\begin{array}{c}0.0001^{* * *} \\
(21.08) \\
\end{array}$ & 0.1909 \\
\hline \multicolumn{13}{|c|}{ Panel B: Subsample Tests Based on Size, $O C_{i, t-1}=M I S V_{i, t-1}$} \\
\hline (1)L & $\begin{array}{c}0.0151^{* * *} \\
(12.89) \\
\end{array}$ & $\begin{array}{c}-0.0021^{* * *} \\
(-19.26) \\
\end{array}$ & $\begin{array}{c}-0.0019^{* * *} \\
(-8.81) \\
\end{array}$ & $\begin{array}{c}-0.0010^{* * *} \\
(-8.61) \\
\end{array}$ & $\begin{array}{c}-0.0001 \\
(-1.02) \\
\end{array}$ & $\begin{array}{c}-0.0002^{* * *} \\
(-8.31) \\
\end{array}$ & $\begin{array}{c}-0.0021^{* * *} \\
(-8.79) \\
\end{array}$ & $\begin{array}{c}0.0055^{* * *} \\
(4.56) \\
\end{array}$ & $\begin{array}{c}0.0002^{* * *} \\
(5.93) \\
\end{array}$ & $\begin{array}{c}-0.0001^{* *} \\
(-2.49) \\
\end{array}$ & $\begin{array}{c}-0.0014^{* * *} \\
(-7.63) \\
\end{array}$ & 0.1616 \\
\hline (2)M & $\begin{array}{c}0.0028^{* * *} \\
(28.33) \\
\end{array}$ & $\begin{array}{c}-0.0006^{* * *} \\
(-27.51) \\
\end{array}$ & $\begin{array}{c}-0.0001^{*} \\
(-1.87) \\
\end{array}$ & $\begin{array}{c}0.0000^{* * *} \\
(-5.51) \\
\end{array}$ & $\begin{array}{c}-0.0001^{* *} \\
(-2.43) \\
\end{array}$ & $\begin{array}{c}-0.0001^{* * *} \\
(-11.28) \\
\end{array}$ & $\begin{array}{c}-0.0010^{* * *} \\
(-13.81) \\
\end{array}$ & $\begin{array}{c}0.0037^{* * *} \\
(15.19) \\
\end{array}$ & $\begin{array}{c}0.0001^{* * *} \\
(8.72) \\
\end{array}$ & $\begin{array}{l}0.0000 \\
(-0.15) \\
\end{array}$ & $\begin{array}{c}0.0003^{* * *} \\
(13.19) \\
\end{array}$ & 0.1689 \\
\hline$(3) \mathrm{H}$ & $\begin{array}{c}0.0013^{* * *} \\
(30.49) \\
\end{array}$ & $\begin{array}{c}-0.0002^{* * *} \\
(-15.98) \\
\end{array}$ & $\begin{array}{c}-0.0001^{* *} \\
(-2.54) \\
\end{array}$ & $\begin{array}{c}0.0000^{* * *} \\
(-9.92) \\
\end{array}$ & $\begin{array}{c}-0.0001^{* * *} \\
(-4.63) \\
\end{array}$ & $\begin{array}{c}-0.0001^{* * *} \\
(-16.80) \\
\end{array}$ & $\begin{array}{c}-0.0007^{* * *} \\
(-14.15) \\
\end{array}$ & $\begin{array}{c}0.0053^{* * *} \\
(8.02)\end{array}$ & $\begin{array}{c}0.0001^{* * *} \\
(26.21)\end{array}$ & $\begin{array}{c}0.0000^{* * *} \\
(-3.11)\end{array}$ & $\begin{array}{c}0.0001^{* * *} \\
(14.41)\end{array}$ & 0.1583 \\
\hline
\end{tabular}




\begin{tabular}{|c|c|c|c|c|c|c|c|c|c|c|c|c|}
\hline & Intercept & $R E T_{i, t-1}$ & $S I Z E_{i, t-1}$ & $L E V_{i, t-1}$ & $A G E_{i, t}$ & $P R C_{i, t-1}$ & $R O E_{i, t-1}$ & $V R O E_{i, t-1}$ & $G O_{i, t-1}$ & $V G O_{i, t-1}$ & $O C_{i, t-1}$ & Adj. $R^{2}$ \\
\hline \multicolumn{13}{|c|}{ Panel C: Subsample Tests Based on Age, $O C_{i, t-1}=T O_{i, t-1}$} \\
\hline (1)L & $\begin{array}{c}0.0050^{* * *} \\
(16.18) \\
\end{array}$ & $\begin{array}{c}-0.0016^{* * *} \\
(-18.55) \\
\end{array}$ & $\begin{array}{c}-0.0016^{* * *} \\
(-9.55) \\
\end{array}$ & $\begin{array}{l}0.0000 \\
(-0.74) \\
\end{array}$ & $\begin{array}{c}-0.0001 \\
(-1.51) \\
\end{array}$ & $\begin{array}{c}0.0000^{*} \\
(-1.77) \\
\end{array}$ & $\begin{array}{c}-0.0016^{* * *} \\
(-6.89) \\
\end{array}$ & $\begin{array}{c}0.0084^{* * *} \\
(6.89) \\
\end{array}$ & $\begin{array}{c}0.0000^{* *} \\
(2.20) \\
\end{array}$ & $\begin{array}{c}-0.0001^{* * *} \\
(-3.98) \\
\end{array}$ & $\begin{array}{c}0.0002^{* * *} \\
(16.78) \\
\end{array}$ & 0.1867 \\
\hline (2)M & $\begin{array}{c}0.0033^{* * *} \\
(11.33) \\
\end{array}$ & $\begin{array}{c}-0.0014^{* * *} \\
(-21.00) \\
\end{array}$ & $\begin{array}{c}-0.0014^{* * *} \\
(-5.79)\end{array}$ & $\begin{array}{c}0.0001^{* * *} \\
(3.13) \\
\end{array}$ & $\begin{array}{c}0.0000 \\
(0.02) \\
\end{array}$ & $\begin{array}{c}0.0001^{* *} \\
(2.57)\end{array}$ & $\begin{array}{c}-0.0019^{* * *} \\
(-8.90)\end{array}$ & $\begin{array}{c}0.0023^{* * *} \\
(2.74) \\
\end{array}$ & $\begin{array}{c}0.0002^{* * *} \\
(7.63) \\
\end{array}$ & $\begin{array}{l}0.0000 \\
(-1.61) \\
\end{array}$ & $\begin{array}{c}0.0002^{* * *} \\
(11.02) \\
\end{array}$ & 0.1974 \\
\hline$(3) \mathrm{H}$ & $\begin{array}{c}0.0022^{* * *} \\
(21.72) \\
\end{array}$ & $\begin{array}{c}-0.0008^{* * *} \\
(-20.03) \\
\end{array}$ & $\begin{array}{c}-0.0006^{* * *} \\
(-3.97) \\
\end{array}$ & $\begin{array}{c}0.0000^{* *} \\
(2.13) \\
\end{array}$ & $\begin{array}{c}-0.0005^{* * *} \\
(-10.74) \\
\end{array}$ & $\begin{array}{c}0.0001^{* * *} \\
(4.25) \\
\end{array}$ & $\begin{array}{c}-0.0022^{* * *} \\
(-10.57) \\
\end{array}$ & $\begin{array}{c}0.0089^{* * *} \\
(10.80) \\
\end{array}$ & $\begin{array}{c}0.0002^{* * *} \\
(6.16) \\
\end{array}$ & $\begin{array}{c}0.0004^{* * *} \\
(4.45) \\
\end{array}$ & $\begin{array}{c}0.0002^{* * *} \\
(11.98) \\
\end{array}$ & 0.2422 \\
\hline \multicolumn{13}{|c|}{ Panel D: Subsample Tests Based on Age, $O C_{i, t-1}=M I S V_{i, t-1}$} \\
\hline (1)L & $\begin{array}{c}0.0051^{* * *} \\
(16.22) \\
\end{array}$ & $\begin{array}{c}-0.0015^{* * *} \\
(-18.32) \\
\end{array}$ & $\begin{array}{c}-0.0015^{* * *} \\
(-9.02)\end{array}$ & $\begin{array}{l}0.0000 \\
(-1.50) \\
\end{array}$ & $\begin{array}{c}0.0000 \\
(0.29) \\
\end{array}$ & $\begin{array}{l}0.0000 \\
(-1.22) \\
\end{array}$ & $\begin{array}{c}-0.0016^{* * *} \\
(-6.83)\end{array}$ & $\begin{array}{c}0.0083^{* * *} \\
(6.72)\end{array}$ & $\begin{array}{c}0.0000 \\
(1.61) \\
\end{array}$ & $\begin{array}{c}-0.0001^{* * *} \\
(-3.49) \\
\end{array}$ & $\begin{array}{c}0.0006^{* * *} \\
(10.16) \\
\end{array}$ & 0.1842 \\
\hline (2)M & $\begin{array}{c}0.0032^{* * *} \\
(11.45) \\
\end{array}$ & $\begin{array}{c}-0.0014^{* * *} \\
(-20.34) \\
\end{array}$ & $\begin{array}{c}-0.0013^{* * *} \\
(-5.18) \\
\end{array}$ & $\begin{array}{c}0.0001^{* * *} \\
(3.58) \\
\end{array}$ & $\begin{array}{c}0.0001 \\
(1.03) \\
\end{array}$ & $\begin{array}{c}0.0001^{*} \\
(1.87) \\
\end{array}$ & $\begin{array}{c}-0.0019 * * * \\
(-9.12) \\
\end{array}$ & $\begin{array}{c}0.0026^{* * *} \\
(3.20) \\
\end{array}$ & $\begin{array}{c}0.0002^{* * *} \\
(7.35) \\
\end{array}$ & $\begin{array}{c}-0.0001^{*} \\
(-1.68) \\
\end{array}$ & $\begin{array}{c}0.0004^{* * *} \\
(7.48) \\
\end{array}$ & 0.1964 \\
\hline (3) $\mathrm{H}$ & $\begin{array}{c}0.0022^{* * *} \\
(20.89) \\
\end{array}$ & $\begin{array}{c}-0.0007^{* * *} \\
(-19.74) \\
\end{array}$ & $\begin{array}{c}-0.0005^{* * *} \\
(-3.26)\end{array}$ & $\begin{array}{c}0.0000^{*} \\
(1.95) \\
\end{array}$ & $\begin{array}{c}-0.0004^{* * *} \\
(-7.63)\end{array}$ & $\begin{array}{c}0.0000^{* * *} \\
(3.15) \\
\end{array}$ & $\begin{array}{c}-0.0023^{* * *} \\
(-11.09) \\
\end{array}$ & $\begin{array}{c}0.0090^{* * *} \\
(10.93) \\
\end{array}$ & $\begin{array}{c}0.0002^{* * *} \\
(5.10) \\
\end{array}$ & $\begin{array}{c}0.0004^{* * *} \\
(4.44) \\
\end{array}$ & $\begin{array}{c}0.0004^{* * *} \\
(12.63) \\
\end{array}$ & 0.2377 \\
\hline \multicolumn{13}{|c|}{ Panel E: Subsample Tests Based on Stock Price, $O C_{i, t-1}=T O_{i, t-1}$} \\
\hline$(1) \mathrm{L}$ & $\begin{array}{c}0.0100^{* * *} \\
(14.76) \\
\end{array}$ & $\begin{array}{c}-0.0028^{* * *} \\
(-18.40) \\
\end{array}$ & $\begin{array}{c}-0.0021^{* * *} \\
(-9.94) \\
\end{array}$ & $\begin{array}{c}-0.0004^{* * *} \\
(-7.28) \\
\end{array}$ & $\begin{array}{c}0.0005^{* * *} \\
(2.83) \\
\end{array}$ & $\begin{array}{c}-0.0003^{* * *} \\
(-10.24) \\
\end{array}$ & $\begin{array}{c}-0.0017^{* * *} \\
(-9.07) \\
\end{array}$ & $\begin{array}{c}0.0035^{* * *} \\
(3.78) \\
\end{array}$ & $\begin{array}{c}0.0001^{* *} \\
(2.47) \\
\end{array}$ & $\begin{array}{c}-0.0001^{* *} \\
(-2.16) \\
\end{array}$ & $\begin{array}{c}0.0005^{* * *} \\
(10.17) \\
\end{array}$ & 0.1480 \\
\hline (2)M & $\begin{array}{c}0.0022^{* * *} \\
(28.81) \\
\end{array}$ & $\begin{array}{c}-0.0004^{* * *} \\
(-13.93) \\
\end{array}$ & $\begin{array}{c}-0.0002^{* * *} \\
(-3.33) \\
\end{array}$ & $\begin{array}{c}-0.0001^{* * *} \\
(-13.20)\end{array}$ & $\begin{array}{c}-0.0002^{* * *} \\
(-10.22) \\
\end{array}$ & $\begin{array}{c}-0.0001^{* * *} \\
(-22.63) \\
\end{array}$ & $\begin{array}{c}-0.0007^{* * *} \\
(-16.34)\end{array}$ & $\begin{array}{c}0.0031^{* * *} \\
(10.87) \\
\end{array}$ & $\begin{array}{c}0.0001^{* * *} \\
(19.26) \\
\end{array}$ & $\begin{array}{l}0.0000 \\
(-0.60) \\
\end{array}$ & $\begin{array}{c}0.0001^{* * *} \\
(21.83) \\
\end{array}$ & 0.1116 \\
\hline$(3) \mathrm{H}$ & $\begin{array}{c}0.0009^{* * *} \\
(37.53) \\
\end{array}$ & $\begin{array}{c}-0.0001^{* * *} \\
(-12.61) \\
\end{array}$ & $\begin{array}{c}0.0000 \\
(1.29) \\
\end{array}$ & $\begin{array}{c}0.0000^{* * *} \\
(-20.91) \\
\end{array}$ & $\begin{array}{c}-0.0001^{* * *} \\
(-4.78)\end{array}$ & $\begin{array}{c}0.0000 * * * \\
(-13.69) \\
\end{array}$ & $\begin{array}{c}-0.0004^{* * *} \\
(-11.04)\end{array}$ & $\begin{array}{c}0.0025^{* * *} \\
(5.59) \\
\end{array}$ & $\begin{array}{c}0.0001^{* * *} \\
(25.40) \\
\end{array}$ & $\begin{array}{c}0.0000 \\
(0.50) \\
\end{array}$ & $\begin{array}{c}0.0001^{* * *} \\
(21.14) \\
\end{array}$ & 0.1471 \\
\hline \multicolumn{13}{|c|}{ Panel F: Subsample Tests Based on Stock Price, $O C_{i, t-1}=M I S V_{i, t-1}$} \\
\hline$(1) \mathrm{L}$ & $\begin{array}{c}0.0108^{* * *} \\
(15.09) \\
\end{array}$ & $\begin{array}{c}-0.0029^{* * *} \\
(-18.07) \\
\end{array}$ & $\begin{array}{c}-0.0019^{* * *} \\
(-9.29)\end{array}$ & $\begin{array}{c}-0.0004^{* * *} \\
(-7.05)\end{array}$ & $\begin{array}{c}0.0001 \\
(0.39) \\
\end{array}$ & $\begin{array}{c}-0.0003^{* * *} \\
(-10.93) \\
\end{array}$ & $\begin{array}{c}-0.0018^{* * *} \\
(-9.48) \\
\end{array}$ & $\begin{array}{c}0.0038^{* * *} \\
(4.16) \\
\end{array}$ & $\begin{array}{c}0.0001^{* * *} \\
(3.31) \\
\end{array}$ & $\begin{array}{c}-0.0001^{*} \\
(-1.83) \\
\end{array}$ & $\begin{array}{c}-0.0012^{* * *} \\
(-7.21) \\
\end{array}$ & 0.1454 \\
\hline$(2) \mathrm{M}$ & $\begin{array}{c}0.0021^{* * *} \\
(28.64) \\
\end{array}$ & $\begin{array}{c}-0.0004^{* * *} \\
(-13.76) \\
\end{array}$ & $\begin{array}{l}0.0000 \\
(-0.92) \\
\end{array}$ & $\begin{array}{c}0.0000 * * * \\
(-9.93) \\
\end{array}$ & $\begin{array}{c}-0.0001^{* * *} \\
(-8.52)\end{array}$ & $\begin{array}{c}-0.0001^{* * *} \\
(-24.82) \\
\end{array}$ & $\begin{array}{c}-0.0007^{* * *} \\
(-17.51) \\
\end{array}$ & $\begin{array}{c}0.0036^{* * *} \\
(11.39) \\
\end{array}$ & $\begin{array}{c}0.0001^{* * *} \\
(20.03) \\
\end{array}$ & $\begin{array}{c}0.0000 \\
(0.47) \\
\end{array}$ & $\begin{array}{c}0.0002^{* * *} \\
(10.31) \\
\end{array}$ & 0.0964 \\
\hline$(3) \mathrm{H}$ & $\begin{array}{c}0.0010^{* * *} \\
(33.06)\end{array}$ & $\begin{array}{c}-0.0001^{* * *} \\
(-12.19)\end{array}$ & $\begin{array}{l}0.0002^{* * *} \\
(5.68)\end{array}$ & $\begin{array}{c}0.0000 * * * \\
(-23.79)\end{array}$ & $\begin{array}{c}0.0000^{* *} \\
(-2.18)\end{array}$ & $\begin{array}{c}0.0000 * * * \\
(-15.80)\end{array}$ & $\begin{array}{c}-0.0005^{* * *} \\
(-11.85)\end{array}$ & $\begin{array}{l}0.0025^{* * *} \\
(5.84)\end{array}$ & $\begin{array}{c}0.0001^{* * *} \\
(27.73)\end{array}$ & $\begin{array}{c}0.0000 \\
(1.59)\end{array}$ & $\begin{array}{c}0.0001^{* * *} \\
(14.62)\end{array}$ & 0.1210 \\
\hline
\end{tabular}


Table V: Cross-Sectional Tests in Subperiods

For each month between $01 / 1976$ and 12/2005, idiosyncratic risk, $V_{i, t}$, is cross-sectionally regressed on overconfidence measures and some control variables. $R E T_{i, t}$ is the stock return. $S I Z E_{i, t}$ is the $\log$ of the market capitalization of firm $i . L E V_{i, t}$ is the leverage ratio calculated by dividing total liabilities by total assets. $A G E_{i, t}$ is the $\log$ of the number of years since firm $i$ 's first appearance in the CRSP. $P R C_{i, t}$ is the stock price. $R O E_{i, t}$ is the return on equity. $G O_{i, t}$ measures the long-term growth option and is free of the influence of misvaluation. $T O_{i, t}$ is the stock turnover. $M I S V_{i, t}$ is the misvaluation of firm $i$ 's stock. $V R O E_{i, t}$ and $V G O_{i, t}$ are time-series variances of the corresponding measures based on data in the previous 36 months. The averages of the estimated coefficients for each fiver-year-subperiod are multiplied by 100 and reported. The numbers in parentheses are $t$-ratios based on the time-series means and standard errors of the estimated coefficients. ***, **, and * denote significance at the $1 \%$, $5 \%$, and $10 \%$ level, respectively.

$V_{i, t}=\beta_{0}+\beta_{1} R E T_{i, t-1}+\beta_{2} S I Z E_{i, t-1}+\beta_{3} L E V_{i, t-1}+\beta_{4} A G E_{i, t}+\beta_{5} P R C_{i, t-1}+\beta_{6} R O E_{i, t-1}+\beta_{7} V R O E_{i, t-1}+\beta_{8} G O_{i, t-1}+$ $\beta_{9} V G O_{i, t-1}+\beta_{10} O C_{i, t-1}+\epsilon_{i, t}$.

Panel A: OC=Stock Turnover

\begin{tabular}{|c|c|c|c|c|c|c|c|c|c|c|c|}
\hline Intercept & $R E T_{i, t-1}$ & $S I Z E_{i, t-1}$ & $L E V_{i, t-1}$ & $A G E_{i, t}$ & $P R C_{i, t-1}$ & $R O E_{i, t-1}$ & $V R O E_{i, t-1}$ & $G O_{i, t-1}$ & $V G O_{i, t-1}$ & $T O_{i, t-1}$ & $A d j . R^{2}$ \\
\hline $\begin{array}{l}0.1618^{* * *} \\
(19.26)\end{array}$ & $\begin{array}{c}-0.0161 \\
(-1.58) \\
\end{array}$ & $\begin{array}{c}-0.0182^{* * *} \\
(-24.63) \\
\end{array}$ & $\begin{array}{c}0.0505^{* * *} \\
(11.92) \\
\end{array}$ & $\begin{array}{c}0.0044^{* * *} \\
(7.89) \\
\end{array}$ & $\begin{array}{c}1976.01-1980.12 \\
-0.0002^{* * *} \\
(-6.88) \\
\end{array}$ & $\begin{array}{c}-0.2882^{* * *} \\
(-18.26) \\
\end{array}$ & $\begin{array}{c}1.3625^{* * *} \\
(11.97) \\
\end{array}$ & $\begin{array}{c}0.0633^{* * *} \\
(17.19) \\
\end{array}$ & $\begin{array}{c}-0.0316^{* * *} \\
(-5.10)\end{array}$ & $\begin{array}{c}0.0076^{* * *} \\
(3.98) \\
\end{array}$ & 0.2298 \\
\hline $\begin{array}{l}0.2170^{* * *} \\
(20.23) \\
\end{array}$ & $\begin{array}{c}-0.0912^{* * *} \\
(-5.60)\end{array}$ & $\begin{array}{c}-0.0157^{* * *} \\
(-20.23) \\
\end{array}$ & $\begin{array}{c}0.0284^{* * *} \\
(6.39) \\
\end{array}$ & $\begin{array}{c}-0.0046^{* * *} \\
(-5.53)\end{array}$ & $\begin{array}{c}1981.01-1985.12 \\
-0.0003^{* * *} \\
(-7.46) \\
\end{array}$ & $\begin{array}{c}-0.1744^{* * *} \\
(-6.06) \\
\end{array}$ & $\begin{array}{c}0.9355^{* * *} \\
(8.40) \\
\end{array}$ & $\begin{array}{c}0.0195^{* * *} \\
(9.31) \\
\end{array}$ & $\begin{array}{c}-0.0082^{* * *} \\
(-3.00) \\
\end{array}$ & $\begin{array}{c}0.0150^{* * *} \\
(7.44) \\
\end{array}$ & 0.1290 \\
\hline $\begin{array}{l}0.6056^{* * *} \\
(16.32) \\
\end{array}$ & $\begin{array}{c}-0.2321^{* * *} \\
(-8.14)\end{array}$ & $\begin{array}{c}-0.0435^{* * *} \\
(-14.74) \\
\end{array}$ & $\begin{array}{c}0.0409^{* * *} \\
(2.59) \\
\end{array}$ & $\begin{array}{c}-0.0067^{* * *} \\
(-4.51) \\
\end{array}$ & $\begin{array}{c}1986.01-1990.12 \\
0.0000^{* *} \\
(2.06) \\
\end{array}$ & $\begin{array}{c}-0.2742^{* * *} \\
(-12.25) \\
\end{array}$ & $\begin{array}{c}0.7708^{* * *} \\
(12.57) \\
\end{array}$ & $\begin{array}{c}0.0022^{* *} \\
(2.11) \\
\end{array}$ & $\begin{array}{c}-0.0015^{* *} \\
(-2.44) \\
\end{array}$ & $\begin{array}{c}0.0078^{* * *} \\
(4.22) \\
\end{array}$ & 0.0862 \\
\hline $\begin{array}{l}1.1786^{* * *} \\
(24.10) \\
\end{array}$ & $\begin{array}{c}-0.3464^{* * *} \\
(-5.57)\end{array}$ & $\begin{array}{c}-0.0992 * * * \\
(-23.85) \\
\end{array}$ & $\begin{array}{c}0.0869^{* * * *} \\
(5.88) \\
\end{array}$ & $\begin{array}{c}0.0195^{* * *} \\
(8.82) \\
\end{array}$ & $\begin{array}{c}1991.01-1995.12 \\
0.0000^{* * *} \\
(10.27) \\
\end{array}$ & $\begin{array}{c}-0.5104^{* * *} \\
(-11.09) \\
\end{array}$ & $\begin{array}{c}0.5725^{* * *} \\
(5.02) \\
\end{array}$ & $\begin{array}{c}0.0641^{* * * *} \\
(10.57) \\
\end{array}$ & $\begin{array}{c}-0.0044^{* *} \\
(-2.57) \\
\end{array}$ & $\begin{array}{c}-0.0008 \\
(-0.20) \\
\end{array}$ & 0.1021 \\
\hline $\begin{array}{l}1.0026^{* * *} \\
(21.66) \\
\end{array}$ & $\begin{array}{c}-0.2965^{* * *} \\
(-6.63) \\
\end{array}$ & $\begin{array}{c}-0.0758^{* * *} \\
(-20.99) \\
\end{array}$ & $\begin{array}{c}-0.0002 \\
(-0.02) \\
\end{array}$ & $\begin{array}{c}0.0022 \\
(0.89) \\
\end{array}$ & $\begin{array}{c}1996.01-2000.12 \\
0.0000^{* * *} \\
(15.49) \\
\end{array}$ & $\begin{array}{c}-0.4331^{* * *} \\
(-9.06) \\
\end{array}$ & $\begin{array}{c}1.5710^{* * *} \\
(8.12) \\
\end{array}$ & $\begin{array}{c}0.0386^{* * *} \\
(6.38) \\
\end{array}$ & $\begin{array}{c}-0.0004 \\
(-0.17) \\
\end{array}$ & $\begin{array}{c}0.0131^{* * *} \\
(6.61) \\
\end{array}$ & 0.1039 \\
\hline $\begin{array}{l}0.6454^{* * *} \\
(11.13)\end{array}$ & $\begin{array}{c}-0.1891^{* * * *} \\
(-3.53)\end{array}$ & $\begin{array}{c}-0.0473^{* * *} \\
(-10.22)\end{array}$ & $\begin{array}{c}0.0392 \\
(1.44)\end{array}$ & $\begin{array}{c}-0.0006 \\
(-0.36)\end{array}$ & $\begin{array}{c}2001.01-2005.12 \\
0.0000^{* * *} \\
(7.39)\end{array}$ & $\begin{array}{c}-0.2909 * * * \\
(-7.05)\end{array}$ & $\begin{array}{c}0.9459 * * * \\
(3.80)\end{array}$ & $\begin{array}{c}0.0164^{* * * *} \\
(6.43)\end{array}$ & $\begin{array}{c}0.0007 \\
(0.55)\end{array}$ & $\begin{array}{c}0.0089^{* * * *} \\
(5.92)\end{array}$ & 0.1095 \\
\hline
\end{tabular}




\begin{tabular}{|c|c|c|c|c|c|c|c|c|c|c|c|}
\hline \multicolumn{12}{|c|}{ Panel B: OC=Stock Misvaluation } \\
\hline Intercept & $R E T_{i, t-1}$ & $S I Z E_{i, t-1}$ & $L E V_{i, t-1}$ & $A G E_{i, t}$ & $P R C_{i, t-1}$ & $R O E_{i, t-1}$ & $V R O E_{i, t-1}$ & $G O_{i, t-1}$ & $V G O_{i, t-1}$ & $M I S V_{i, t-1}$ & $A d j . R^{2}$ \\
\hline $\begin{array}{l}0.1437^{* * *} \\
(17.09)\end{array}$ & $\begin{array}{c}-0.0102 \\
(-0.96)\end{array}$ & $\begin{array}{c}-0.0163^{* * *} \\
(-21.13) \\
\end{array}$ & $\begin{array}{c}0.0606^{* * *} \\
(15.19)\end{array}$ & $\begin{array}{c}0.0027^{* * *} \\
(4.56)\end{array}$ & $\begin{array}{c}1976.01-1980.12 \\
-0.0002^{* * *} \\
(-7.69)\end{array}$ & $\begin{array}{c}-0.2913^{* * *} \\
(-18.52)\end{array}$ & $\begin{array}{c}1.3997^{* * *} \\
(12.26)\end{array}$ & $\begin{array}{c}0.0578^{* * *} \\
(15.71)\end{array}$ & $\begin{array}{c}-0.0300^{* * *} \\
(-4.89)\end{array}$ & $\begin{array}{c}0.0403^{* * *} \\
(13.13)\end{array}$ & 0.2314 \\
\hline $\begin{array}{l}0.2020^{* * *} \\
(20.43)\end{array}$ & $\begin{array}{c}-0.0859^{* * *} \\
(-5.33)\end{array}$ & $\begin{array}{c}-0.0144^{* * *} \\
(-19.33)\end{array}$ & $\begin{array}{c}0.0349^{* * *} \\
(7.95)\end{array}$ & $\begin{array}{c}-0.0046^{* * *} \\
(-5.56)\end{array}$ & $\begin{array}{c}1981.01-1985.12 \\
-0.0003^{* * *} \\
(-7.84)\end{array}$ & $\begin{array}{c}-0.1784^{* * *} \\
(-6.24)\end{array}$ & $\begin{array}{c}0.9297^{* * *} \\
(8.10)\end{array}$ & $\begin{array}{c}0.0180^{* * *} \\
(9.32)\end{array}$ & $\begin{array}{c}-0.0079 * * * \\
(-2.92)\end{array}$ & $\begin{array}{c}0.0279^{* * *} \\
(9.09)\end{array}$ & 0.1280 \\
\hline $\begin{array}{l}0.5707^{* * *} \\
(15.82)\end{array}$ & $\begin{array}{c}-0.2290^{* * *} \\
(-8.11)\end{array}$ & $\begin{array}{c}-0.0417^{* * *} \\
(-14.69)\end{array}$ & $\begin{array}{c}0.0566^{* * *} \\
(3.47)\end{array}$ & $\begin{array}{c}-0.0061^{* * *} \\
(-4.05)\end{array}$ & $\begin{array}{c}1986.01-1990.12 \\
0.0000^{*} \\
(1.86)\end{array}$ & $\begin{array}{c}-0.2729 * * * \\
(-12.00)\end{array}$ & $\begin{array}{c}0.7112^{* * *} \\
(11.65)\end{array}$ & $\begin{array}{c}0.0005 \\
(0.47)\end{array}$ & $\begin{array}{c}-0.0016^{* * *} \\
(-2.63)\end{array}$ & $\begin{array}{c}0.0596 * * * \\
(9.90)\end{array}$ & 0.0875 \\
\hline $\begin{array}{l}1.1183^{* * *} \\
(24.83)\end{array}$ & $\begin{array}{c}-0.3537 * * * \\
(-5.80)\end{array}$ & $\begin{array}{c}-0.0994^{* * * *} \\
(-24.38)\end{array}$ & $\begin{array}{c}0.1422^{* * *} \\
(8.58)\end{array}$ & $\begin{array}{c}0.0235^{* * *} \\
(10.27)\end{array}$ & $\begin{array}{c}1991.01-1995.12 \\
0.0000^{* * *} \\
(9.98)\end{array}$ & $\begin{array}{c}-0.5087^{* * *} \\
(-10.93)\end{array}$ & $\begin{array}{c}0.4903^{* * *} \\
(4.37)\end{array}$ & $\begin{array}{c}0.0582^{* * * *} \\
(9.81)\end{array}$ & $\begin{array}{c}-0.0045^{* * *} \\
(-2.63)\end{array}$ & $\begin{array}{c}0.1748 * * * \\
(18.56)\end{array}$ & 0.0996 \\
\hline $\begin{array}{l}1.0221^{* * *} \\
(22.08)\end{array}$ & $\begin{array}{c}-0.2792^{* * *} \\
(-6.33)\end{array}$ & $\begin{array}{c}-0.0812^{* * *} \\
(-21.54)\end{array}$ & $\begin{array}{c}0.0480 * * * \\
(4.94)\end{array}$ & $\begin{array}{c}0.0043^{*} \\
(1.68)\end{array}$ & $\begin{array}{c}1996.01-2000.12 \\
0.0000^{* * *} \\
(16.85)\end{array}$ & $\begin{array}{c}-0.4274^{* * * *} \\
(-8.87)\end{array}$ & $\begin{array}{c}1.4470 * * * \\
(7.83)\end{array}$ & $\begin{array}{c}0.0337 * * * \\
(5.58)\end{array}$ & $\begin{array}{c}-0.0003 \\
(-0.13)\end{array}$ & $\begin{array}{c}0.1579 * * * \\
(19.31)\end{array}$ & 0.1072 \\
\hline $\begin{array}{l}0.6284^{* * *} \\
(10.93)\end{array}$ & $\begin{array}{c}-0.1798^{* * *} \\
(-3.30)\end{array}$ & $\begin{array}{c}-0.0471^{* * *} \\
(-10.32)\end{array}$ & $\begin{array}{c}0.0674^{* * * *} \\
(2.58)\end{array}$ & $\begin{array}{c}-0.0015 \\
(-0.96)\end{array}$ & $\begin{array}{c}2001.01-2005.12 \\
0.0000^{* * *} \\
(7.79)\end{array}$ & $\begin{array}{c}-0.2920^{* * *} \\
(-7.13)\end{array}$ & $\begin{array}{c}0.8905^{* * *} \\
(3.63)\end{array}$ & $\begin{array}{c}0.0135^{* * *} \\
(5.50)\end{array}$ & $\begin{array}{c}0.0010 \\
(0.77)\end{array}$ & $\begin{array}{c}0.0825^{* * *} \\
(10.09)\end{array}$ & 0.1108 \\
\hline
\end{tabular}


Table VI: Idiosyncratic Risk and Investor Overconfidence: Time-Series Tests

The monthly value-weighted idiosyncratic risk, $V_{t}$, is regressed on a time trend measure $t$ and the overconfidence measures. $S E N T_{t}^{\perp}$ is the monthly investor sentiment index taken from Jeffrey Wurgler's homepage. $T O_{t}$ is the value-weighted stock turnover. $M I S V_{t}$ is the value-weighted misvaluation of stocks. $M I S V_{t}$ covers the period from $01 / 1976$ to $12 / 2005$. All other data cover the period from $01 / 1971$ to $12 / 2005$. The numbers in parentheses are $t$-ratios based on Newy-West standard errors with 12 -month lags. ${ }^{* * *}, * *$, and $*$ denote significance at the $1 \%, 5 \%$, and $10 \%$ level, respectively.

$V_{t}=\beta_{0}+\beta_{1} t+\beta_{2} O C_{t-1}+\epsilon_{t}$.

\begin{tabular}{|c|c|c|c|c|}
\hline \multicolumn{5}{|c|}{ Panel A: $S E N T_{t-1}^{\perp}-$ Sentiment Index } \\
\hline & Intercept & $t$ & $S E N T_{t-1}^{\perp}$ & $\operatorname{Adj} . R^{2}$ \\
\hline (1) & $\begin{array}{c}0.005922^{* * * *} \\
(5.18)\end{array}$ & $\begin{array}{c}0.000014^{*} \\
(1.78)\end{array}$ & & 0.0773 \\
\hline$(2)$ & $\begin{array}{c}0.006936^{* * * *} \\
(6.70)\end{array}$ & $\begin{array}{c}0.000010^{*} \\
(1.65)\end{array}$ & $\begin{array}{c}0.002124^{* *} \\
(2.09)\end{array}$ & 0.1653 \\
\hline \multicolumn{5}{|c|}{ Panel B: $T O_{t-1}-$ Stock Turnover } \\
\hline & Intercept & $t$ & $T O_{t-1}$ & Adj.R $R^{2}$ \\
\hline (1) & $\begin{array}{c}0.004656^{* * *} \\
(4.16)\end{array}$ & $\begin{array}{c}0.000018^{* *} \\
(2.25)\end{array}$ & & 0.1266 \\
\hline$(2)$ & $\begin{array}{c}0.005243^{* * * *} \\
(5.34)\end{array}$ & $\begin{array}{c}-0.000030^{*} \\
(-1.69)\end{array}$ & $\begin{array}{c}0.014365^{* *} \\
(2.18)\end{array}$ & 0.2867 \\
\hline \multicolumn{5}{|c|}{ Panel C: $M I S V_{t-1}-$ Stock Misvaluation } \\
\hline & Intercept & $t$ & $M I S V_{t-1}$ & Adj. $R^{2}$ \\
\hline$(1)$ & $\begin{array}{c}0.00537^{* * *} \\
(4.27)\end{array}$ & $\begin{array}{c}0.000017^{* *} \\
(1.82)\end{array}$ & & 0.0887 \\
\hline$(2)$ & $\begin{array}{c}0.001149 \\
(0.74)\end{array}$ & $\begin{array}{c}-0.000010^{* *} \\
(-1.84)\end{array}$ & $\begin{array}{c}0.025766^{* * *} \\
(4.05)\end{array}$ & 0.4615 \\
\hline
\end{tabular}




\section{Table VII: Profitability, Growth options, and Overconfidence}

The monthly value-weighted idiosyncratic risk, $V_{t}$, is regressed on a time trend measure $t$, the overconfidence measures, and the profitability and growth option measures. $S E N T_{t}^{\perp}$ is the investor sentiment index taken from Jeffrey Wurgler's homepage. $T O_{t}$ is the value-weighted stock turnover. $M I S V_{t}$ measures misvaluation. $R O E_{t}$ is the value-weighted return on equity in month $t . G O_{t}$ is the value-weighted measure of the long-term growth option. The time-series variances of individual stocks' return on equity and long-term growth option over the previous 36 months are calculated and value weighted to get $V R O E_{t}$ and $V G O_{t}$, respectively. Data cover the period 01/1976-12/2005. The estimated coefficients over the whole sample period are multiplied by 100 and reported. The numbers in parentheses are $t$-ratios based on Newy-West standard errors with 12-month lags. ***, **, and * denote significance at the $1 \%, 5 \%$, and $10 \%$ level, respectively.

\begin{tabular}{|c|c|c|c|c|c|c|c|}
\hline & (1) & $(2)$ & (3) & (4) & (5) & (6) & (7) \\
\hline Intercept & $\begin{array}{c}0.4657^{* * *} \\
(4.52)\end{array}$ & $\begin{array}{c}0.5017^{* * *} \\
(4.97)\end{array}$ & $\begin{array}{c}0.2204^{*} \\
(1.68)\end{array}$ & $\begin{array}{c}0.1213 \\
(0.89)\end{array}$ & $\begin{array}{c}-4.4450^{* * *} \\
(-4.82)\end{array}$ & $\begin{array}{c}-4.4670^{* * *} \\
(-5.18)\end{array}$ & $\begin{array}{c}-2.0220 \\
(-1.38)\end{array}$ \\
\hline$t$ & $\begin{array}{c}0.0020^{* *} \\
(2.14)\end{array}$ & $\begin{array}{c}0.0018^{* *} \\
(2.32)\end{array}$ & $\begin{array}{c}-0.0040^{* * *} \\
(-2.60)\end{array}$ & $\begin{array}{c}-0.0020^{* *} \\
(-2.03)\end{array}$ & $\begin{array}{c}-0.0040^{* * *} \\
(-3.39)\end{array}$ & $\begin{array}{c}-0.0060^{* * *} \\
(-5.09)\end{array}$ & $\begin{array}{c}-0.0040^{* * *} \\
(-3.02)\end{array}$ \\
\hline$S E N T_{t-1}^{\perp}$ & & $\begin{array}{c}0.2249^{* *} \\
(2.17)\end{array}$ & & & $\begin{array}{c}0.1164^{* * *} \\
(2.66)\end{array}$ & & \\
\hline$T O_{t-1}$ & & & $\begin{array}{c}1.9228^{* * *} \\
(3.33)\end{array}$ & & & $\begin{array}{c}0.9319^{* * *} \\
(3.64)\end{array}$ & \\
\hline$M I S V_{t-1}$ & & & & $\begin{array}{c}2.6304^{* * *} \\
(4.19)\end{array}$ & & & $\begin{array}{c}1.2366^{* *} \\
(2.56)\end{array}$ \\
\hline$R O E_{t-1}$ & & & & & $\begin{array}{r}-4.8190 \\
(-0.47)\end{array}$ & $\begin{array}{r}-1.2040 \\
(-0.15)\end{array}$ & $\begin{array}{c}2.1849 \\
(0.19)\end{array}$ \\
\hline$V R O E_{t-1}$ & & & & & $\begin{array}{c}96.5320 \\
(0.72)\end{array}$ & $\begin{array}{c}38.0726 \\
(0.38)\end{array}$ & $\begin{array}{l}4.4702 \\
(0.03)\end{array}$ \\
\hline$G O_{t-1}$ & & & & & $\begin{array}{c}3.8737 * * * \\
(4.15)\end{array}$ & $\begin{array}{c}3.6782^{* * * *} \\
(4.45)\end{array}$ & $\begin{array}{l}1.6937 \\
(1.22)\end{array}$ \\
\hline$V G O_{t-1}$ & & & & & $\begin{array}{l}5.9111 \\
(1.59)\end{array}$ & $\begin{array}{l}4.6986 \\
(1.42)\end{array}$ & $\begin{array}{c}8.7212^{* *} \\
(2.51)\end{array}$ \\
\hline $\operatorname{Adj} . R^{2}$ & 0.1224 & 0.2329 & 0.3859 & 0.4994 & 0.5993 & 0.6155 & 0.5964 \\
\hline
\end{tabular}


Table VIII: Time-Series Subsample Tests based on Age

For each month, stocks are divided into young and old groups based on their age, which is counted from their first appearance in the CRSP to the end of the last year. Stocks are sorted based on age, and those that fall into the lowest and highest thirtieth percentiles are classified as young and old, respectively. Within each group, idiosyncratic risk, $V_{t}$, is regressed on a time trend measure $t$, profitability, growth option, and the overconfidence measures. $R O E_{t}$ is the value-weighted return on equity in month $t$. $G O_{t}$ is the value-weighted measure of the long-term growth option. $S E N T_{t}^{\perp}$ is the investor sentiment index taken from Jeffrey Wurgler's homepage. $T O_{t}$ is the value-weighted stock turnover. $M I S V_{t}$ measures misvaluation. The time-series variances of individual stocks' return on equity and long-term growth option over the previous 36 months are calculated and value weighted to get $V R O E_{t}$ and $V G O_{t}$, respectively. Data cover the period 01/1976-12/2005. The numbers in parentheses are $t$-ratios based on Newy-West standard errors with 12 -month lags. ${ }^{* * *},{ }^{* *}$, and $*$ denote significance at the $1 \%, 5 \%$, and $10 \%$ level, respectively.

$V_{t}=\beta_{0}+\beta_{1} t+\beta_{2} R O E_{t-1}+\beta_{3} V R O E_{t-1}+\beta_{4} G O_{t-1}+\beta_{5} V G O_{t-1}+\beta_{6} O C_{t-1}+\epsilon_{t}$.

Panel A: Young Stocks

\begin{tabular}{|c|c|c|c|c|c|c|c|c|}
\hline & Intercept & $t$ & $R O E_{t-1}$ & $V R O E_{t-1}$ & $G O_{t-1}$ & $V G O_{t-1}$ & $O C_{t-1}$ & Adj. $R^{2}$ \\
\hline (1) No $O C_{t-}$ & $\begin{array}{c}0.012477 \\
(1.06)\end{array}$ & $\begin{array}{c}-0.000050^{* *} \\
(-2.48)\end{array}$ & $\begin{array}{c}-0.298950 * * * \\
(-3.03)\end{array}$ & $\begin{array}{l}2.741446^{* * *} \\
(3.75)\end{array}$ & $\begin{array}{c}0.007899 \\
(0.89)\end{array}$ & $\begin{array}{c}-0.037710^{*} \\
(-1.76)\end{array}$ & & 0.4886 \\
\hline (2) $O C_{t-1}=S E N T_{t-1}^{\perp}$ & $\begin{array}{l}0.021370^{* *} \\
\quad(2.11)\end{array}$ & $\begin{array}{c}-0.000050^{* * *} \\
(-3.14)\end{array}$ & $\begin{array}{c}-0.241370^{* * *} \\
(-2.96)\end{array}$ & $\begin{array}{c}2.850983^{* * *} \\
(4.85)\end{array}$ & $\begin{array}{c}0.000417 \\
(0.05)\end{array}$ & $\begin{array}{c}-0.034700^{*} \\
(-1.69)\end{array}$ & $\begin{array}{c}0.003561^{* * *} \\
(3.20)\end{array}$ & 0.5437 \\
\hline (3) $O C_{t-1}=T O_{t-1}$ & & $\begin{array}{c}-0.000100^{* * * *} \\
(-5.23)\end{array}$ & $\begin{array}{c}-0.101520^{*} \\
(-1.70)\end{array}$ & $\begin{array}{c}1.367447^{* * *} \\
(4.65)\end{array}$ & $\begin{array}{c}0.012968^{* *} \\
(2.12)\end{array}$ & & $\begin{array}{c}0.016123^{* * *} \\
(5.13)\end{array}$ & 0.6146 \\
\hline (4) $O C_{t-1}=M I S V_{t-1}$ & $\begin{array}{c}0.016166 \\
(1.49) \\
\end{array}$ & $\begin{array}{c}-0.000050^{* * *} \\
(-3.04) \\
\end{array}$ & $\begin{array}{c}-0.254520^{* * *} \\
(-3.69) \\
\end{array}$ & $\begin{array}{c}1.250262^{* * *} \\
(2.97)\end{array}$ & $\begin{array}{c}-0.000630 \\
(-0.07) \\
\end{array}$ & $\begin{array}{c}-0.024660 \\
(-1.28) \\
\end{array}$ & $\begin{array}{c}0.035202^{* * *} \\
(4.40)\end{array}$ & 0.5797 \\
\hline \multicolumn{9}{|c|}{ Panel B: Old Stocks } \\
\hline & Intercept & $t$ & $R O E_{t-1}$ & $V R O E_{t-1}$ & $G O_{t-1}$ & $V G O_{t-1}$ & $O C_{t-1}$ & Adj. $R^{2}$ \\
\hline \multirow{2}{*}{$\begin{array}{l}\text { (1) No } O C_{t-1} \\
\text { (2) } O C_{t-1}=S E N T_{t-1}^{\perp}\end{array}$} & $\begin{array}{c}-0.046970 * * * \\
(-2.61)\end{array}$ & $\begin{array}{c}-0.000007 \\
(-0.77)\end{array}$ & $\begin{array}{l}-0.068540 \\
(-1.09)\end{array}$ & $\begin{array}{c}-0.323580 \\
(-0.38)\end{array}$ & $\begin{array}{c}0.040592^{* * *} \\
(2.76)\end{array}$ & $\begin{array}{l}0.010758 \\
(0.38)\end{array}$ & & 0.4032 \\
\hline & $\begin{array}{c}-0.043100^{* * *} \\
(-3.06)\end{array}$ & $\begin{array}{c}-0.000020^{* *} \\
(-2.09)\end{array}$ & $\begin{array}{c}-0.034810 \\
(-0.66)\end{array}$ & $\begin{array}{l}0.781023 \\
(0.88)\end{array}$ & $\begin{array}{c}0.036796^{* * *} \\
(3.17)\end{array}$ & $\begin{array}{c}0.013149 \\
(0.48)\end{array}$ & $\begin{array}{c}0.001457^{* * *} \\
(4.37)\end{array}$ & 0.4847 \\
\hline (3) $O C_{t-1}=T O_{t-1}$ & $\begin{array}{c}-0.054470 * * * \\
(-3.29)\end{array}$ & $\begin{array}{c}-0.000030^{* * * *} \\
(-2.96)\end{array}$ & $\begin{array}{c}-0.023460 \\
(-0.51)\end{array}$ & $\begin{array}{l}0.128962 \\
(0.18)\end{array}$ & $\begin{array}{c}0.043436^{* * *} \\
(3.38)\end{array}$ & $\begin{array}{c}-0.016210 \\
(-0.56)\end{array}$ & $\begin{array}{c}0.010038^{* * *} \\
(3.26)\end{array}$ & 0.4735 \\
\hline (4) $O C_{t-1}=M I S V_{t-1}$ & $\begin{array}{c}-0.019280 \\
(-1.24) \\
\end{array}$ & $\begin{array}{c}-0.000010 \\
(-1.25) \\
\end{array}$ & $\begin{array}{c}-0.025210 \\
(-0.44) \\
\end{array}$ & $\begin{array}{c}-0.375930 \\
(-0.48) \\
\end{array}$ & $\begin{array}{c}0.017373 \\
(1.38) \\
\end{array}$ & $\begin{array}{c}0.018719 \\
(0.70) \\
\end{array}$ & $\begin{array}{c}0.010780^{* * *} \\
(3.00)\end{array}$ & 0.4444 \\
\hline
\end{tabular}




\section{Table IX: Time-Series Subsample Tests based on Exchange Market}

For each month, stocks are divided into NYSE/AMEX and NASDAQ stocks, based on where they are listed. Within each group, the monthly value-weighted idiosyncratic risk, $V_{t}$, is regressed on a time trend measure $t$, profitability, growth option, and the overconfidence measures. $R O E_{t}$ is the value-weighted return on equity in month $t . G O_{t}$ is the value-weighted measure of the longterm growth option. $S E N T_{t}^{\perp}$ is the investor sentiment index taken from Jeffrey Wurgler's homepage. $T O_{t}$ is the value-weighted stock turnover. MISV $V_{t}$ measures misvaluation. The time-series variances of individual stocks' return on equity and long-term growth option over the previous 36 months are calculated and value weighted to get $V R O E_{t}$ and $V G O_{t}$, respectively. Data cover the period 01/1976-12/2005. The numbers in parentheses are $t$-ratios based on Newy-West standard errors with 12-month lags. $* * *, * *$, and $*$ denote significance at the $1 \%, 5 \%$, and $10 \%$ level, respectively.

$V_{t}=\beta_{0}+\beta_{1} t+\beta_{2} R O E_{t-1}+\beta_{3} V R O E_{t-1}+\beta_{4} G O_{t-1}+\beta_{5} V G O_{t-1}+\beta_{6} O C_{t-1}+\epsilon_{t}$.

Panel A: NYSE/AMEX Stocks

\begin{tabular}{|c|c|c|c|c|c|c|c|c|}
\hline & Intercept & $t$ & $R O E_{t-1}$ & $V R O E_{t-1}$ & $G O_{t-1}$ & $V G O_{t-1}$ & $O C_{t-1}$ & Adj. $R^{2}$ \\
\hline $\begin{array}{l}\text { (1) No } O C_{t-1} \\
\text { (2) } O C_{t-1}=S E N T_{t-1}^{\perp} \\
\text { (3) } O C_{t-1}=T O_{t-1} \\
\text { (4) } O C_{t-1}=M I S V_{t-1}\end{array}$ & $\begin{array}{c}-0.036740^{* * *} \\
(-2.90) \\
-0.037490^{* * *} \\
(-3.37) \\
-0.052970^{* * *} \\
(-4.45) \\
-0.023280^{* *} \\
(-1.98) \\
\end{array}$ & $\begin{array}{c}-0.000010 \\
(-1.14) \\
-0.000020^{*} \\
(-1.83) \\
-0.000030^{* * *} \\
(-3.68) \\
-0.000010 \\
(-1.07) \\
\end{array}$ & $\begin{array}{c}-1.140000 \\
(-0.13) \\
-0.012740 \\
(-0.22) \\
0.015068 \\
(0.35) \\
0.006988 \\
(0.12) \\
\end{array}$ & $\begin{array}{c}-1.809930^{*} \\
(-1.83) \\
-0.539580 \\
(-0.53) \\
-1.220390 \\
(-1.42) \\
-1.970380^{* *} \\
(-1.96) \\
\end{array}$ & $\begin{array}{c}0.030196^{* * *} \\
(2.97) \\
0.031223^{* * *} \\
(3.37) \\
0.040285^{* * *} \\
(4.44) \\
0.019232^{* *} \\
(2.00) \\
\end{array}$ & $\begin{array}{c}0.267700^{* * *} \\
(6.39) \\
0.214331^{* * *} \\
(4.53) \\
0.210933^{* * *} \\
(6.25) \\
0.235507^{* * *} \\
(5.06) \\
\end{array}$ & $\begin{array}{c}0.000933^{* * *} \\
(3.18) \\
0.009934^{* * *} \\
(5.00) \\
0.006066^{*} \\
(1.76) \\
\end{array}$ & $\begin{array}{l}0.4356 \\
0.4639 \\
0.4949 \\
0.4438\end{array}$ \\
\hline \multicolumn{9}{|c|}{ Panel B: NASDAQ Stocks } \\
\hline & Intercept & $t$ & $R O E_{t-1}$ & $V R O E_{t-1}$ & $G O_{t-1}$ & $V G O_{t-1}$ & $O C_{t-1}$ & Adj. $R^{2}$ \\
\hline $\begin{array}{l}\text { (1) No } O C_{t-1} \\
\text { (2) } O C_{t-1}=S E N T_{t-1}^{\perp} \\
\text { (3) } O C_{t-1}=T O_{t-1} \\
\text { (4) } O C_{t-1}=M I S V_{t-1}\end{array}$ & $\begin{array}{c}-0.004140 \\
(-0.56) \\
-0.001590 \\
(-0.25) \\
0.007514 \\
(1.54) \\
0.011896^{* *} \\
(2.41) \\
\end{array}$ & $\begin{array}{c}-0.000040 \\
(-1.61) \\
-0.000030 \\
(-1.47) \\
-0.000130^{* * *} \\
(-5.99) \\
-0.000070^{* * *} \\
(-4.56) \\
\end{array}$ & $\begin{array}{c}-0.122380 \\
(-1.18) \\
-0.103980 \\
(-1.01) \\
-0.002000 \\
(-0.03) \\
0.006372 \\
(0.07) \\
\end{array}$ & $\begin{array}{c}3.014911^{*} \\
(1.78) \\
3.040855^{* *} \\
(1.96) \\
1.907097^{* *} \\
(2.22) \\
2.221018^{* * *} \\
(2.84) \\
\end{array}$ & $\begin{array}{c}0.010391 \\
(1.33) \\
0.008385 \\
(1.08) \\
0.001456 \\
(0.30) \\
-0.006520 \\
(-1.14) \\
\end{array}$ & $\begin{array}{c}0.004154 \\
(0.42) \\
0.002311 \\
(0.26) \\
0.010084 \\
(1.53) \\
0.013724^{* *} \\
(2.00) \\
\end{array}$ & $\begin{array}{c}0.001947 \\
(1.27) \\
0.015360^{* * *} \\
(5.94) \\
0.033591^{* * *} \\
(6.03) \\
\end{array}$ & $\begin{array}{l}0.2571 \\
0.2783 \\
0.4521 \\
0.5048\end{array}$ \\
\hline
\end{tabular}

